\title{
Review \\ A Critical Review on Optimization of Cold-Formed Steel Members for Better Structural and Thermal Performances
}

\author{
Hao Liang ${ }^{1}$, Krishanu Roy ${ }^{1,2, *} \mathbb{C}$, Zhiyuan Fang ${ }^{1}$ and James B. P. Lim ${ }^{1,2} \mathbb{C}^{\mathbb{C}}$ \\ 1 Department of Civil and Environmental Engineering, The University of Auckland, Auckland 1010, New Zealand; \\ hlia929@aucklanduni.ac.nz (H.L.); zfan995@aucklanduni.ac.nz (Z.F.); james.lim@auckland.ac.nz (J.B.P.L.) \\ 2 School of Engineering, Civil Engineering, The University of Waikato, Hamilton 3216, New Zealand \\ * Correspondence: kroy405@aucklanduni.ac.nz
}

Citation: Liang, H.; Roy, K.; Fang, Z.; Lim, J.B.P. A Critical Review on Optimization of Cold-Formed Steel Members for Better Structural and Thermal Performances. Buildings 2022, 12, 34. https://doi.org/ 10.3390 /buildings12010034

Academic Editor: Francisco López Almansa

Received: 3 December 2021 Accepted: 28 December 2021 Published: 1 January 2022

Publisher's Note: MDPI stays neutral with regard to jurisdictional claims in published maps and institutional affiliations.

Copyright: (c) 2022 by the authors. Licensee MDPI, Basel, Switzerland. This article is an open access article distributed under the terms and conditions of the Creative Commons Attribution (CC BY) license (https:/ / creativecommons.org/licenses/by/ $4.0 /)$.

\begin{abstract}
The construction and building sectors are currently responsible globally for a significant share of the total energy consumption and energy-related carbon dioxide emissions. The use of Modern Methods of Construction can help reduce this, one example being the use of cold-formed steel (CFS) construction. CFS channel sections have inherent advantages, such as their high strengthto-weight ratio and excellent potential for recycling and reusing. CFS members can be rolled into different cross-sectional shapes and optimizing these shapes can further improve their load-bearing capacities, resulting in a more economical and efficient building solution. Conversely, the high thermal conductivity of steel can lead to thermal bridges, which can significantly reduce the building's thermal performance and energy efficiency. Hence, it is also essential to consider the thermal energy performance of the CFS structures. This paper reviews the existing studies on the structural optimization of CFS sections and the thermal performance of such CFS structures. In total, over 160 articles were critically reviewed. The methodologies used in the existing literature for optimizing CFS members for both structural and thermal performances have been summarized and presented systematically. Research gaps from the existing body of knowledge have been identified, providing guidelines for future research.
\end{abstract}

Keywords: cold-formed steel; cold-formed steel structures; thermal performance; review

\section{Introduction}

Climate change is one of the most critical challenges that the world is facing today. The building sector plays an important role in the energy consumption and emissions released from the buildings [1,2]. Normally, a building uses energy throughout its life cycle, including direct energy used for construction, operation, rehabilitation, and demolition and indirect energy consumed to produce material used in its construction and installations [3]. According to the 2020 Global Status Report for Buildings and Construction [4], building construction and operations accounted for the largest share of the total energy consumption globally (35\%) and energy-related carbon dioxide emissions (38\%). Large construction activity is taking place globally to accommodate the migration of the world's population to urban areas [3]. A study in the UK [5] stated that if without any action, the greenhouse gas emissions from buildings would be more than doubling in the next two decades due to the inefficiencies of the existing building technologies. Such a boom in construction also provides a significant resource-saving potential from depletion. Reducing the environmental impacts of construction and improving the energy efficiency of buildings during their entire life span has become the prime objective throughout the world [6].

Research conducted by McLaren et al. [7] showed that New Zealand needs to reduce $72 \%$ of the carbon footprint of the residential housing construction to stay within the international climate target of maximum global warming by $1.5^{\circ} \mathrm{C}$. Besides, New Zealand recently announced reducing its net greenhouse gas emissions by 50\% within 2030 [8]. Incremental improvements are insufficient, and significant changes are required [7]. These 
efforts include prioritizing retrofitting and renovating existing buildings to reduce operational energy consumption [7]. For new buildings, efforts should be made to reduce operational energy and use environmentally friendly materials [7]. The COVID-19 pandemic has altered people's daily life and brought a lot of changes in the sustainability requirements of the building industry [9]. The three main aspects of residential buildings, health and safety, environment, and comfort, are anticipated to encounter significant transformations to sustainability [9]. For many people, staying at home due to extensively long lockdown periods turns into a new lifestyle, which leads to more consumption of resources, such as energy usage. It highlights the significance of fulfilling rigorous energy-saving provisions for new houses and retrofitting and improving the energy efficiency of the building envelopes [10,11].

The type and amount of building materials used in the construction industry substantially impact the carbon footprint [12]. Cold-formed steel (CFS) is considered a suitable material to build energy-efficient buildings [13]. Steel has a near 100\% recycling rate, maximizing the materials' efficiency and reducing waste [14,15]. Recycled steel is used in most steel products, including steel framing, which comprises at least $25 \%$ recycled steel [16]. Steel has never been downcycled in the same way as other construction materials, the recycling material of poorer quality and functioning than the original material [14]. For example, the fibers shorten when the wood is chopped, while recycling steel preserves all of its properties on a molecular level, providing more robustness [14]. In addition, steel profiles have a high strength-to-weight ratio, and less maintenance is required for steel structures as they are not sensitive to moisture or biological activities [10,14-19]. CFS members are rolled at ambient temperature from thin gauge steel sheets [20]. They have many advantages over traditional hot-rolled steel members, such as a higher strengthto-weight ratio, a highly flexible manufacturing process, and being light weight leads to easier handling, transportation, and erection [20-27]. CFS sections are used extensively in roof and wall systems, steel storage racks, and many other similar secondary load-bearing members $[20,21,28-34]$. In recent years, using CFS is also a popular choice in modular construction, which is an alternative way to conventional on-site construction [35-43].

The growing world population and limitations of natural resources have increased the need for more cost-effective structural systems to implement a sustainable economy and society [44]. CFS can be rolled to form a great variety of shapes, which provides a unique opportunity to further increase the load-carrying capacity of these cross-sections through optimization processes [45-47]. However, CFS members have some drawbacks concerning its thermal behavior, primarily induced by the high thermal conductivity of the steel, which can result in a large amount of heat loss or gain through the thermal bridging and adversely affect the thermal performance of the buildings $[18,48]$. Hence, in order to reach a high level of sustainability and energy efficiency, it is important to improve the design of CFS structures. Further understanding the optimization and thermal performance could help researchers conduct sustainable design in energy dissipation, structural capacity, and material cost.

This paper brings together the existing research on the structural optimization of CFS sections and the thermal performance of CFS framed structures to provide an overview of how CFS construction can contribute to a more sustainable built environment. In total, over 160 papers were reviewed, which were published in the literature from the year of 1997 to 2021. The majority of the papers are relevant to structural behavior and structural optimization of CFS. However, 40 papers were concerning the thermal performance of CFS members and their thermal insulation. The methodologies used in the existing literature and their findings are critically analyzed and presented systematically. From the existing body of knowledge, research gaps were identified, providing recommendations for future research. 


\section{Structural Optimization of CFS Members}

Structural optimization usually includes optimization of dimension, shape, and topology [49]. Dimensional optimization works on a fixed topology by changing individual dimensions [49]. Shape optimization requires the use of a shape generation subroutine to adjust the member's geometry for improved performance, but the connectivity or topology may not be significantly altered [49]. Topology optimization provides the most flexibility in terms of generating an optimal shape within an assigned domain of material connection and can be changed by adding voids [49].

\subsection{Cross-Sectional Shapes of CFS Members}

\subsubsection{CFS Single Sections}

Figure 1 shows several typical cross-sections of CFS members. As a result of current trends, CFS sections become thinner and more highly stiffened, which are then more prone to local and distortional buckling [50,51]. Therefore, more complex shapes are being created to increase the buckling resistance $[28,52,53]$. For example, as shown in Figure 2, more complex shapes are created from simple lipped channels to include multiple segments, stiffeners, and lips. Substantial research in terms of experimental and numerical investigations of CFS sections behavior has revealed that adding intermediate web stiffeners and edge stiffeners enhances the strengths of such sections [54-65].

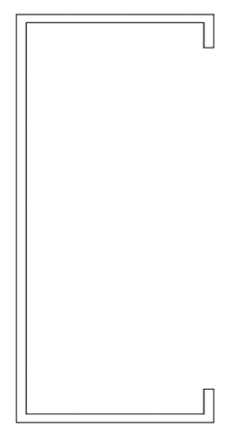

(a)

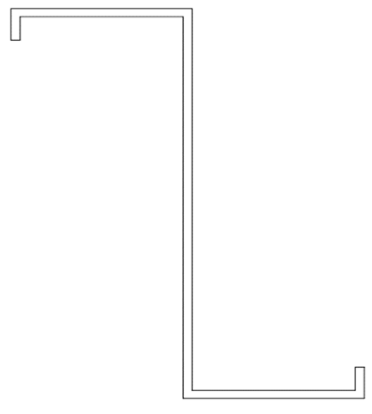

(b)

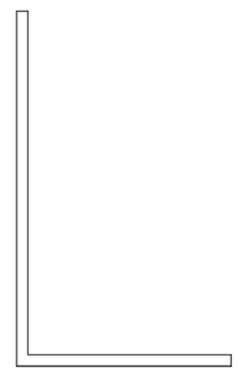

(c)

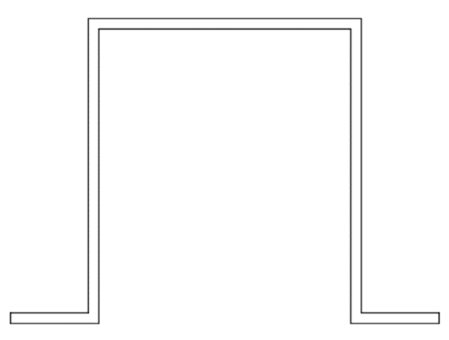

(d)

Figure 1. Cross sections of a typical (a) "C" shaped section; (b) " $Z$ " shaped section; (c) " $L$ " shaped section; (d) Hat-shaped section.

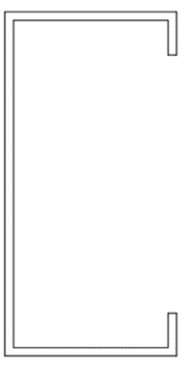

(a)

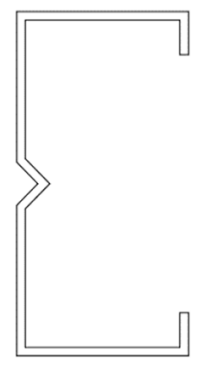

(b)

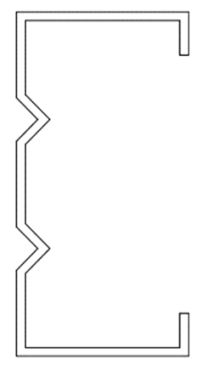

(c)

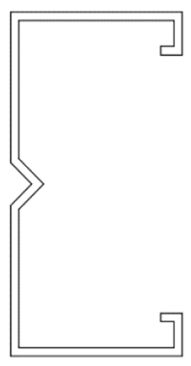

(d)

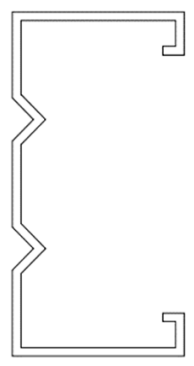

(e)

Figure 2. Different cross-sections of (a) A simple lipped channel; (b) A lipped channel with one web stiffener; (c) A lipped channel with two web stiffeners; (d) A channel section with one web stiffener and return lips; (e) A channel section with two web stiffeners and return lips.

\subsubsection{CFS Built-Up Sections}

The literature has considered different cross-sectional geometries of CFS built-up sections [66-90]. As can be seen from Figure 3, the built-up channel sections are formed from two identical lipped channel sections connected face-to-face to form a box section, 
or back-to-back to form an I-section or back-to-back gapped built-up sections. Such built-up CFS sections can span further and can achieve higher compression and bending capacities $[54,70,76]$.

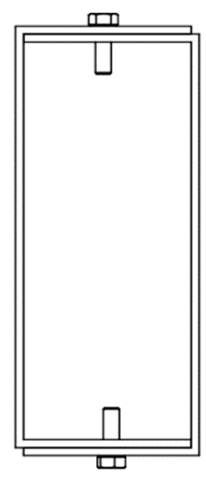

(a)

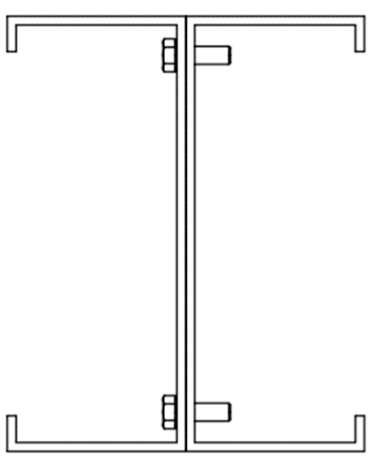

(b)

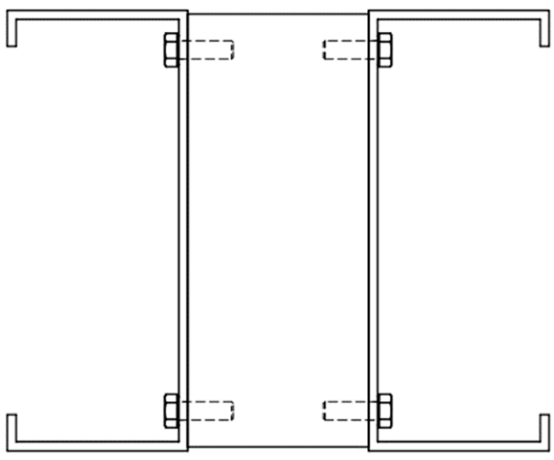

(c)

Figure 3. (a) Face-to-face connected box-section; (b) back-to-back built-up I-section; (c) back-to-back gapped built-up channel sections.

\subsection{Structural Behaviour of CFS Members}

Previous studies have shown that CFS beams and columns are mainly affected by local, distortional, and global buckling or interaction between them (Figure 4) $[45,54,69,75,91-98]$. All buckling modes are dependent on the condition of end supports, different loading types, and cross-sectional shapes of CFS members [75]. Moreover, the web crippling is another failure for flexural members of a CFS open section [99-101].

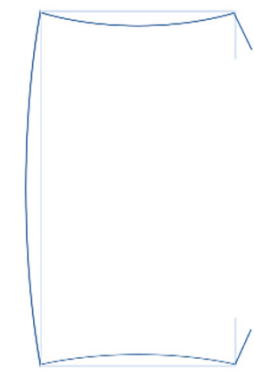

(a)

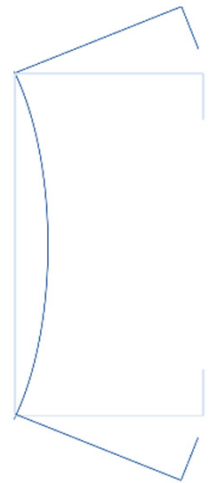

(b)

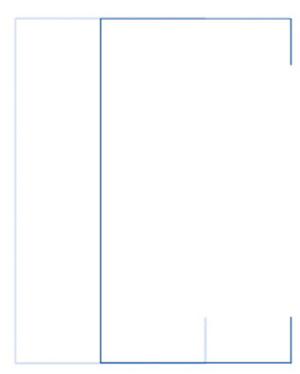

(c)

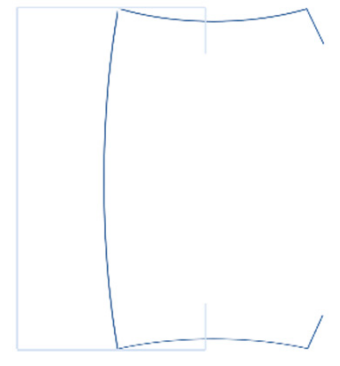

(d)

Figure 4. The buckling modes of CFS lipped channel sections with conditions of (a) local, (b) distortional, (c) global, and (d) local-flexural interactive buckling.

\subsubsection{Current Design Methods}

The most commonly used design codes for CFS structures are the North American Specification, which is also known as American Iron and Steel Institute (AISI) [102], the Australian/New Zealand Standard (AZ/NZS) [103], and Eurocode [104]. They formally provide two design methods to predict the axial strength of columns and the flexural capacity of beams, the long-established Effective Width Method (EWM) and the more newly developed Direct Strength Method (DSM) [105]. The calculation process in the EWM may be tedious for complex cross-sectional shapes, while the DSM is much simpler [106]. 


\subsubsection{Effective Width Method (EWM)}

Following AS/NZS 4600:2018 [103], the axial capacity $\left(N^{*}\right)$ is computed by Equations (1) and (2).

$$
\begin{aligned}
& N^{*} \leq \varnothing_{c} N_{s}=\varnothing_{c} A_{e} f_{y} \\
& N^{*} \leq \varnothing_{c} N_{c}=\varnothing_{c} A_{e} f_{n}
\end{aligned}
$$

where $\varnothing_{c}=$ capacity reduction factor for compression members, $N_{s}=$ nominal section capacity of the compression members, $N_{c}=$ nominal member capacity of the compression members, $A_{e}=$ effective area, $f_{y}=$ yield stress, and $f_{n}=$ critical stress.

$f_{n}$ is determined by,

$$
\begin{gathered}
f_{n}=\left(0.658^{\lambda_{c}{ }^{2}}\right) f_{y}, \quad \text { for } \lambda_{c} \leq 1.5 \\
f_{n}=\left(\frac{0.877}{\lambda_{c}^{2}}\right) f_{y}, \quad \text { for } \lambda_{c}>1.5 \\
\lambda_{c}=\sqrt{\frac{f_{y}}{f_{o c}}}
\end{gathered}
$$

where $\lambda_{c}=$ non-dimensional slenderness, and $f_{o c}=$ the minimum among the elastic flexural, torsional, and flexural-torsional buckling stress.

The design bending moment $\left(M^{*}\right)$ of the flexural member is computed by Equations (6) and (7).

$$
\begin{aligned}
& M^{*} \leq \varnothing_{b} M_{s}=\varnothing_{b} Z_{e} f_{y} \\
& M^{*} \leq \varnothing_{b} M_{b}=\varnothing_{b} Z_{c} f_{c}
\end{aligned}
$$

where $\varnothing_{b}=$ capacity reduction factor for bending, $M_{s}=$ nominal section moment capacity, $M_{b}=$ nominal member moment capacity, $Z_{e}=$ effective section modulus.

$f_{c}$ is determined by,

$$
f_{c}=\frac{M_{c}}{Z_{f}}
$$

where $M_{c}=$ critical moment and $Z_{f}=$ full unreduced section modulus.

\subsubsection{Direct Strength Method (DSM)}

According to AISIS100-16 [102], the column nominal axial strength $\left(P_{n}\right)$ is determined by

$$
P_{n}=\min \left(P_{n D}, P_{n G}, P_{n L}\right)
$$

where $M_{n D}, M_{n G}$, and $M_{n L}$ are given by Equations (10)-(12), respectively.

The axial strength for distortional buckling $\left(P_{n D}\right)$ can be calculated by Equation (10).

$$
\begin{cases}P_{n D}=P_{y} & \text { if } \lambda_{D} \leq 0.561 \\ P_{n D}=P_{y}\left(\frac{P_{c r D}}{P_{y}}\right)^{0.6}\left[1-0.25\left(\frac{P_{c r D}}{P_{y}}\right)^{0.6}\right], & \text { if } \lambda_{D}>0.561\end{cases}
$$

where $\lambda_{D}=\sqrt{\frac{P_{y}}{P_{c r D}}}$ is the distortional slenderness and $P_{c r D}$ is the critical distortional buckling load.

The axial strength for global buckling $\left(P_{n G}\right)$ can be calculated by Equation (11).

$$
\begin{cases}P_{n G}=P_{y} 0.658^{\lambda_{G}{ }^{2},} & \text { if } \lambda_{G} \leq 1.5 \\ P_{n G}=P_{y} \frac{0.877}{\lambda_{G}{ }^{2}}, & \text { if } \lambda_{G}>1.5\end{cases}
$$

where $\lambda_{G}=\sqrt{\frac{P_{y}}{P_{c r G}}}$ is the global slenderness and $P_{c r G}$ is the critical global buckling load. 
The axial strength for local buckling $\left(P_{n L}\right)$ can be calculated by Equation (12).

$$
\begin{cases}P_{n L}=P_{y,} & \text { if } \lambda_{L} \leq 0.776 \\ P_{n L}=P_{y}\left(\frac{P_{c r L}}{P_{y}}\right)^{0.4}\left[1-0.15\left(\frac{P_{c r L}}{P_{y}}\right)^{0.4}\right], & \text { if } \lambda_{L}>0.776\end{cases}
$$

where $\lambda_{L}=\sqrt{\frac{P_{y}}{P_{c r L}}}$ is the local slenderness, $P_{y}$ is the squash load, and $P_{c r L}$ is the critical local buckling load.

The beam nominal bending capacity $\left(M_{n}\right)$ is determined by

$$
M_{n}=\min \left(M_{n D}, M_{n G}, M_{n L}\right),
$$

where $M_{n D}, M_{n G}$, and $M_{n L}$ are given by Equations (14)-(16), respectively.

The nominal moment capacity for distortional buckling $\left(M_{n D}\right)$ beams can be calculated by Equation (14).

$$
\begin{cases}M_{n D}=M_{y}, & \text { if } \lambda_{D} \leq 0.673 \\ M_{n D}=M_{y}\left(\frac{M_{c r D}}{M_{y}}\right)^{0.5}\left[1-0.22\left(\frac{M_{c r D}}{M_{y}}\right)^{0.5}\right], & \text { if } \lambda_{D}>0.673\end{cases}
$$

where $\lambda_{D}=\sqrt{\frac{M_{y}}{M_{c r D}}}$ is the distortional slenderness, $M_{y}$ is the cross-section first yield moment $\left(M_{y}=S_{f} f_{y}\right.$, where $S_{f}$ is the gross section elastic modulus), and $M_{c r D}$ is the critical distortional buckling moment.

The nominal moment capacity for global buckling of beams $\left(M_{n G}\right)$ can be calculated by Equation (15).

$$
\left\{\begin{array}{lr}
M_{n G}=M_{c r G}, & \text { if } M_{c r G}<0.56 M_{y} \\
M_{n G}=\frac{10}{9} M_{y}\left(1-\frac{10 M_{y}}{36 M_{c r G}}\right), & \text { if } 2.78 M_{y} \geq M_{c r G} \geq 0.56 M_{y} \\
M_{n G}=M_{y}, & \text { if } M_{c r G}>2.78 M_{y}
\end{array}\right.
$$

where $M_{c r G}$ is the critical global buckling moment.

The nominal moment capacity for local buckling $\left(M_{n L}\right)$ of beams can be calculated by Equation (16).

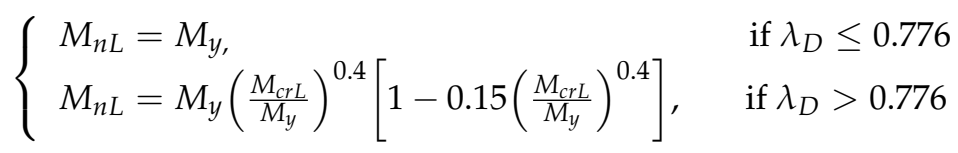

where $\lambda_{L}=\sqrt{\frac{M_{y}}{M_{c r L}}}$ is the local slenderness and $M_{c r L}$ is the critical local buckling moment.

\subsubsection{Other Methods}

Deep Belief Network (DBN) has been demonstrated to be a useful approach for studying the structural performance of CFS sections [107-110]. DBN is a representative and effective deep-learning method [107]. Generative model and back-propagation algorithms are used in the pretraining procedure and fine-tuning stage, respectively, which enables the excellent ability of DBN to make data regression and prediction work with confined training samples $[107,108]$. DBN can be trained to display the high-dimensional data characteristics, and it is also a fast-learning algorithm to obtain near-optimal parameters [107].

\subsection{Optimization Algorithms}

\subsubsection{Stochastic Search Algorithms}

GA is found to be the most popular stochastic search algorithms used in the context of CFS structures. Acceptable results have also been achieved by using other stochastic methods, such as PSO and SA. 
GA is applicable for searching the entire problem space. However, it is stochastic, and no guarantee can be made to achieve the global optimal results [49]. Besides, GA is an unconstrained optimization algorithm, which means any constraint has to be incorporated directly into the objective function through an augmented Lagrangian approach or penalty factors [49]. Gatheeshgar et al. [111] indicated that one of the significant advantages of PSO over GA is that the practical manufacturing and theoretical constraints could be incorporated easily in the case of PSO. Leng et al.'s study [81] preferred SA more than GA since it ran only on one design instead of a population and led to computational cost savings [112].

A direct comparison between the performance of GA, SA, and the gradient-based steepest descent method was carried out by Leng et al. [113]. For the same computing efforts, GA and SA provided comparable optimal solutions, while the gradient-based method only achieved local optima, which was dependent on the initial geometry. However, gradientbased optimization can be a useful tool to refine solutions obtained at the beginning stage, as it is computationally efficient and has good convergence.

Other derivative-free algorithms mentioned in the literature on CFS optimization include the Ant colony-based optimization (ACO) and the artificial neural network (ANN).

\subsubsection{Ant Colony-Based Optimization (ACO)}

The ACO is inspired by the behavior of ants seeking a path between their colony and a source of food [49]. The developments of some of the most robust metaheuristics, such as ACO in recent decades, have enabled the analyst to solve large combinatorial optimization problems that can be reduced to finding the shortest paths through graph theory models [114]. Sharafi et al. [114] used this theory-based graphical method for shape and size optimizations of CFS members.

\subsubsection{Artificial Neural Network (ANN)}

ANN is a popular machine learning and data mining model and mimics biological neural networks. An ANN is made up of three parts: a network with a well-organized topology of linked nodes, a technique for encoding information, and a way for retrieving information [49]. Several studies available in the literature used ANN to optimize the cross-sections of CFS members, as discussed in the next section of the paper.

\subsection{Existing Studies in the Literature for Structural Optimization of CFS Sections}

CFS members may be rolled to nearly any open cross-section to meet specific objectives $[20,21,113,115]$. However, this flexibility sometimes can make it a hard choice for cross-section selections [116-118]. With the recent push for lighter and greener buildings, finding the optimal cross-sectional shape for CFS members is of great interest $[112,113,115]$. Extensive research has been conducted on the structural optimization of CFS members subject to different loading conditions. Table 1 summarizes the research works performed over the last two decades to optimize different cross-sections of CFS members.

A variety of optimization techniques have been used in the earlier research to optimize CFS members, such as graph theory and ant colony optimization [114], Genetic Algorithms (GA) [20,50,98,113,117-124], Particle Swarm Optimization (PSO) [21,91,111,125-130], Direct Multi Search Optimization (DMS) [115], the Big Bang-Big Crunch algorithm (BBBC) [131], self-shape optimization method [132], parameter-free method [133], Neutral Dynamic model [23,134,135], Simulated Annealing (SA) [112,113,124,136], the Gradient Descent Optimization (GDO) [113,122], the Trust-Region Method (TRM) [116], and Whale Optimization Algorithm (WOA) [37].

These optimization studies can also be split into two groups: (i) optimization without any constraints on the overall cross-sectional shape (unconstrained shape optimization) [113-115,121,123,132,137]; and (ii) optimization of the dimensions of a predefined cross-sectional shape (constrained shape optimization) [20,21,50,91,98,112,116-120,122, 124-131,134,136,138-140].The latter one is more practical and easier to manufacture. More 
recently, nonlinear Finite Element (FE) models have been widely applied in assessing the accuracy of optimization results $[21,119,123,125-128,130,131]$.

\subsubsection{Optimization Objective}

A typical engineering design objective in structural optimization is to minimize the weight of structural members, simultaneously meeting strength and serviceability constraints. This objective was pursued by optimizing individual cross-sectional shapes [114,116,118,123,134-136,138,139]. Adeli and Karim [135] developed a computational neural network model which guaranteed a local optimum solution. Tian and $\mathrm{Lu}$ [138] performed a combined theoretical and experimental study on the minimum weight and the associated optimal geometric dimensions of channel columns with and without lips according to provisions of BS 5950-5 [141]. Tran and Li [116] researched the global optimization of CFS channel beams subjected to uniformly distributed transverse loading. Lee et al. [118] used a micro genetic algorithm (MGA) to find an optimum cross-section of CFS channel beams under uniformly distributed loads. They indicated that MGAs showed excellent performance on seeking the minimum weight design of CFS channel beams [118]. Guimarães et al. [123] optimized the shape of singly symmetric CFS purlins to minimize the cross-sectional area while satisfying the strength requirements. According to their results, the optimized purlins saved up to $6.6 \%$ of steel compared to the reference purlins. This cost-saving in the material was quite notable for a mass-produced product such as purlins [123].

Instead of attempting to find the minimum weight for a predefined cross-section shape, the first traceable work of maximizing the CFS member's strength for a given amount of material by changing its shape appeared to be Liu et al. [137]. The optimized CFS section exhibited up to $300 \%$ improvement in strength over the commonly used channel sections [137].

\subsubsection{Optimization of CFS Beams}

Ostwald and Rodak [139] analyzed the optimal design of CFS beams with open shapes subjected to different loading conditions. In their work, the concept of Pareto optimality was used to solve the multi-criteria optimization problem. The cross-section area was considered the first objective function, and the beam deflection was considered the second one [139]. Ye et al. [126] conducted a comprehensive investigation on the practical optimization of CFS beams using the PSO method, and significant strength improvements were obtained. To further improve the capacity of the beams, the researchers optimized a more comprehensive range of cross-sectional shapes, including edge and intermediate stiffeners and segmentally folded flanges [21]. The optimized folded-flange section revealed a bending capacity of up to $57 \%$ higher than the standard optimized shape with the same amount of material [21].

Recently, Gatheeshgar et al. [128] optimized CFS beams using the PSO method. Their results showed that the optimized CFS sections possessed considerable enhancements in the sectional moment capacity, up to $65 \%$ improvement was achieved when compared with the commercially available ones [128]. Moreover, the researchers [111] incorporated the optimized CFS members into modular building systems.

The ultimate capacity was the sole optimization criterion in most of the previous research studies, while Ye et al. [125] investigated the seismic performance of CFS elements by optimizing their geometrical and material properties and also including the post-buckling behavior to reach the maximum level of energy dissipation. Mojtabaei et al. [131] optimized CFS beams with maximum flexural strength and minimum deflection under ultimate and serviceability limit states, respectively. Gatheeshgar et al. [130] optimized CFS lipped channel beams to maximize their combined bending, shear, and web crippling strengths. 
Table 1. Summary of the relevant research studies available in the literature for structural optimization of CFS sections.

\begin{tabular}{|c|c|c|c|c|c|c|c|c|c|c|}
\hline \multirow[b]{2}{*}{ Researcher } & \multirow[b]{2}{*}{ Year } & \multirow[b]{2}{*}{ Element Type } & \multirow[b]{2}{*}{$\begin{array}{c}\text { Fixed } \\
\text { Amount of } \\
\text { Material }\end{array}$} & \multirow[b]{2}{*}{$\begin{array}{c}\text { Design } \\
\text { Specification }\end{array}$} & \multicolumn{3}{|c|}{ Constraints Imposed } & \multirow[b]{2}{*}{$\begin{array}{l}\text { Optimization } \\
\text { Method }\end{array}$} & \multirow[b]{2}{*}{$\begin{array}{l}\text { Validated by } \\
\text { FEA }\end{array}$} & \multirow[b]{2}{*}{ Conclusions } \\
\hline & & & & & $\begin{array}{c}\text { Geometric } \\
\text { Requirement }\end{array}$ & $\begin{array}{l}\text { Practical \& } \\
\text { Manufactur- } \\
\text { ing } \\
\text { Constraints }\end{array}$ & $\begin{array}{l}\text { Assembly \& } \\
\text { End-Use } \\
\text { Constraints }\end{array}$ & & & \\
\hline Ye et al. [125] & 2018 & Beams & $\checkmark$ & Eurocode 3 & $\checkmark$ & $\checkmark$ & & PSO & $\checkmark$ & $\begin{array}{c}\text { The optimized cross-sectional } \\
\text { shapes can dissipate up to } 60 \% \\
\text { more energy through plastic } \\
\text { deformations. }\end{array}$ \\
\hline Mojtabaei et al. [20] & 2021 & $\begin{array}{l}\text { Single and } \\
\text { built-up } \\
\text { beam-column } \\
\text { members }\end{array}$ & $\checkmark$ & Eurocode 3 & $\checkmark$ & $\checkmark$ & & GA & & $\begin{array}{c}\text { Up to } 156 \% \text { gain in the capacity can } \\
\text { be obtained by the optimized } \\
\text { section. }\end{array}$ \\
\hline Ye et al. [21] & 2016 & Beams & $\checkmark$ & Eurocode 3 & $\checkmark$ & $\checkmark$ & & PSO & $\checkmark$ & $\begin{array}{l}\text { The optimized folded-flange } \\
\text { section can obtain up to a } 57 \% \\
\text { increase in the bending capacity. }\end{array}$ \\
\hline Phan et al. [98] & 2020 & $\begin{array}{l}\text { Built-up beam } \\
\text { sections }\end{array}$ & $\checkmark$ & Eurocode 3 & $\checkmark$ & $\checkmark$ & $\checkmark$ & GA & & $\begin{array}{l}\text { Up to an } 84 \% \text { increase in the } \\
\text { ultimate capacity can be achieved. }\end{array}$ \\
\hline Ma et al. [119] & 2015 & $\begin{array}{l}\text { Beam-column } \\
\text { members }\end{array}$ & $\checkmark$ & Eurocode 3 & $\checkmark$ & & & GA & $\checkmark$ & $\begin{array}{l}\text { Up to } 90 \% \text { gain in capacity can be } \\
\text { achieved for very short columns by } \\
\text { adding strategically placed web } \\
\text { stiffeners or double-fold lips. }\end{array}$ \\
\hline Parastesh et al. [50] & 2019 & $\begin{array}{l}\text { Symmetric } \\
\text { beam-column } \\
\text { members }\end{array}$ & $\checkmark$ & AISI S100 & $\checkmark$ & $\checkmark$ & $\checkmark$ & GA & & $\begin{array}{c}\text { Up to } 63 \%, 94 \% \text {, and } 122 \% \text { increase } \\
\text { in the ultimate strength for short, } \\
\text { medium, and long members, } \\
\text { respectively. }\end{array}$ \\
\hline Mojtabaei et al. [131] & 2019 & Beams & $\checkmark$ & Eurocode 3 & $\checkmark$ & $\checkmark$ & $\checkmark$ & BB-BC & $\checkmark$ & $\begin{array}{l}\text { Up to } 44 \% \text { higher effective stiffness } \\
\text { and } 58 \% \text { higher bending moment } \\
\text { capacity can be obtained by the } \\
\text { optimized section. }\end{array}$ \\
\hline Madeira et al. [115] & 2015 & Columns & $\checkmark$ & AISI S100 & $\checkmark$ & & & DMS & & $\begin{array}{c}\text { The two most effective shapes were } \\
\text { presented in the paper. }\end{array}$ \\
\hline Ye et al. [126] & 2016 & Beams & $\checkmark$ & Eurocode 3 & $\checkmark$ & $\checkmark$ & & $\mathrm{PSO}$ & $\checkmark$ & $\begin{array}{l}\text { Up to } 25 \% \text { and } 75 \% \text { higher flexural } \\
\text { strength can be achieved for } \\
\text { laterally braced and unbraced CFS } \\
\text { beams. }\end{array}$ \\
\hline
\end{tabular}


Table 1. Cont.

\begin{tabular}{|c|c|c|c|c|c|c|c|c|c|c|}
\hline \multirow[b]{2}{*}{ Researcher } & \multirow[b]{2}{*}{ Year } & \multirow[b]{2}{*}{ Element Type } & \multirow[b]{2}{*}{$\begin{array}{c}\text { Fixed } \\
\text { Amount of } \\
\text { Material }\end{array}$} & \multirow[b]{2}{*}{$\begin{array}{c}\text { Design } \\
\text { Specification }\end{array}$} & \multicolumn{3}{|c|}{ Constraints Imposed } & \multirow[b]{2}{*}{$\begin{array}{l}\text { Optimization } \\
\text { Method }\end{array}$} & \multirow[b]{2}{*}{$\begin{array}{l}\text { Validated by } \\
\text { FEA }\end{array}$} & \multirow[b]{2}{*}{ Conclusions } \\
\hline & & & & & $\begin{array}{c}\text { Geometric } \\
\text { Requirement }\end{array}$ & $\begin{array}{l}\text { Practical \& } \\
\text { Manufactur- } \\
\text { ing } \\
\text { Constraints }\end{array}$ & $\begin{array}{l}\text { Assembly \& } \\
\text { End-Use } \\
\text { Constraints }\end{array}$ & & & \\
\hline Perampalam et al. [127] & 2019 & Beams & $\checkmark$ & Eurocode 3 & $\checkmark$ & & & PSO & $\checkmark$ & $\begin{array}{l}\text { A higher flexural capacity of up to } \\
50 \% \text { can be obtained compared to } \\
\text { the benchmark section. }\end{array}$ \\
\hline Lee et al. [117] & 2006 & Columns & $\checkmark$ & AISI S100 & $\checkmark$ & & & $\begin{array}{l}\text { Micro genetic } \\
\text { algorithm } \\
\text { (MGA) }\end{array}$ & & $\begin{array}{l}\text { The lipped-channel section was } \\
\text { found to be about } 15 \% \text { more } \\
\text { efficient than the channel section. }\end{array}$ \\
\hline Gilbert et al. [132] & 2012 & Columns & $\checkmark$ & AS/NZS 4600 & $\checkmark$ & $\checkmark$ & & $\begin{array}{l}\text { Self-shape } \\
\text { optimization } \\
\text { method }\end{array}$ & & $\begin{array}{l}\text { The rounded shapes can increase } \\
\text { the local buckling strength while } \\
\text { maximizing the global buckling } \\
\text { strength. }\end{array}$ \\
\hline Wang et al. [120] & 2016 & Columns & $\checkmark$ & AS/NZS 4600 & $\checkmark$ & $\checkmark$ & $\checkmark$ & GA & & $\begin{array}{c}\text { The optimized solutions doubled } \\
\text { the axial capacity of the } \\
\text { conventional lipped channel } \\
\text { section. }\end{array}$ \\
\hline Leng et al. [112] & 2014 & Columns & $\checkmark$ & AISI S100 & $\checkmark$ & $\checkmark$ & $\checkmark$ & SA & & $\begin{array}{l}\text { The ' } \Sigma \text { '-sections were preferred } \\
\text { due to their ability to provide } \\
\text { robust capacity increases. }\end{array}$ \\
\hline Leng et al. [113] & 2011 & Columns & $\checkmark$ & NA & & & & $\begin{array}{c}\text { GDO, GA and } \\
\text { SA }\end{array}$ & & $\begin{array}{l}\text { The capacities of the optimized } \\
\text { sections were found to be more } \\
\text { than double of the original design. }\end{array}$ \\
\hline Gatheeshgar et al. [128] & 2020 & Beams & $\checkmark$ & Eurocode 3 & $\checkmark$ & $\checkmark$ & & PSO & $\checkmark$ & $\begin{array}{l}\text { Up to } 65 \% \text { enhancements in the } \\
\text { capacity were achieved by the } \\
\text { optimized CFS sections. }\end{array}$ \\
\hline Li et at. [129] & 2016 & $\begin{array}{l}\text { Beam-column } \\
\text { members }\end{array}$ & $\checkmark$ & AISI-S100 & $\checkmark$ & $\checkmark$ & $\checkmark$ & PSO & & $\begin{array}{l}\text { The optimal lipped channel } \\
\text { sections were } 14 \% \text { more efficient. }\end{array}$ \\
\hline Wang et al. [121] & 2016 & $\begin{array}{l}\text { Beam-column } \\
\text { members }\end{array}$ & $\checkmark$ & AS/NZS 4600 & & & & GA & & $\begin{array}{l}\text { An optimized slim "I" type } \\
\text { cross-sectional shape with a curved } \\
\text { web was typically found for the } \\
\text { fully restrained beams, and a large } \\
\text { open channel section with lip } \\
\text { stiffeners was found for the } \\
\text { unrestrained beams. }\end{array}$ \\
\hline
\end{tabular}


Table 1. Cont.

\begin{tabular}{|c|c|c|c|c|c|c|c|c|c|c|}
\hline \multirow[b]{2}{*}{ Researcher } & \multirow[b]{2}{*}{ Year } & \multirow[b]{2}{*}{ Element Type } & \multirow[b]{2}{*}{$\begin{array}{c}\text { Fixed } \\
\text { Amount of } \\
\text { Material }\end{array}$} & \multirow[b]{2}{*}{$\begin{array}{c}\text { Design } \\
\text { Specification }\end{array}$} & \multicolumn{3}{|c|}{ Constraints Imposed } & \multirow[b]{2}{*}{$\begin{array}{l}\text { Optimization } \\
\text { Method }\end{array}$} & \multirow[b]{2}{*}{$\begin{array}{c}\text { Validated by } \\
\text { FEA }\end{array}$} & \multirow[b]{2}{*}{ Conclusions } \\
\hline & & & & & $\begin{array}{c}\text { Geometric } \\
\text { Requirement }\end{array}$ & $\begin{array}{l}\text { Practical \& } \\
\text { Manufactur- } \\
\text { ing } \\
\text { Constraints }\end{array}$ & $\begin{array}{l}\text { Assembly \& } \\
\text { End-Use } \\
\text { Constraints }\end{array}$ & & & \\
\hline Tashakori and Adeli [134] & 2002 & Columns & & AISI S100 & $\checkmark$ & $\checkmark$ & $\checkmark$ & $\begin{array}{l}\text { Neural } \\
\text { dynamics } \\
\text { model }\end{array}$ & & $\begin{array}{l}\text { The optimization model resulted in } \\
\text { substantial savings in the weight of } \\
\text { the structure. }\end{array}$ \\
\hline Tran and Li [116] & 2006 & Beams & & $\begin{array}{l}\text { BS 5950-5 } \\
\text { Eurocode } 3\end{array}$ & $\checkmark$ & & & TRM & & $\begin{array}{l}\text { The two design codes, BS 5950-5 } \\
\text { and Eurocode } 3 \text { provided almost } \\
\text { the same optimized solution. }\end{array}$ \\
\hline Ostwald and Rodak [139] & 2013 & Beams & & NA & $\checkmark$ & $\checkmark$ & & $\begin{array}{l}\text { Pareto concept } \\
\text { of optimality }\end{array}$ & & $\begin{array}{l}\text { The optimal shapes of the } \\
\text { cross-sections under different } \\
\text { loading cases were presented. }\end{array}$ \\
\hline Moharrami et al. [122] & 2014 & Columns & $\checkmark$ & AISI S100 & $\checkmark$ & $\checkmark$ & & GA & & $\begin{array}{l}\text { The optimized sections have } \\
\text { compressive capabilities that are } \\
\text { more than three times larger than } \\
\text { the original designs. }\end{array}$ \\
\hline $\begin{array}{l}\text { Dias and } \\
\text { Mahendran [124] }\end{array}$ & 2021 & Columns & $\checkmark$ & NA & $\checkmark$ & $\checkmark$ & & SA and GA & $\checkmark$ & $\begin{array}{l}\text { Significant strength and efficiency } \\
\text { enhancements were found in the } \\
\text { optimized sections. }\end{array}$ \\
\hline Guimarães et al. [123] & 2021 & Beams & & AS/NZS 4600 & $\checkmark$ & $\checkmark$ & $\checkmark$ & $\begin{array}{l}\text { The } \\
\text { augmented } \\
\text { Lagrangian } \\
\text { genetic } \\
\text { method }\end{array}$ & $\checkmark$ & $\begin{array}{l}\text { The optimized solutions can save } \\
\text { up to } 6.6 \% \text { of steel compared to the } \\
\text { reference purlins. }\end{array}$ \\
\hline Gatheeshgar et al. [130] & 2020 & Beams & $\checkmark$ & Eurocode 3 & $\checkmark$ & $\checkmark$ & & PSO & $\checkmark$ & $\begin{array}{l}\text { The optimized CFS sections were } \\
\text { more effective than the } \\
\text { conventional CFS sections. }\end{array}$ \\
\hline Gatheeshgar et al. [37] & 2021 & Beams & & Eurocode 3 & $\checkmark$ & $\checkmark$ & & WOA & $\checkmark$ & $\begin{array}{l}\text { Up to } 24 \% \text { of weight reduction was } \\
\text { found using the novel optimization } \\
\text { method without compromising the } \\
\text { capacity. }\end{array}$ \\
\hline Gatheeshgar et al. [111] & 2020 & Beams & $\checkmark$ & Eurocode 3 & $\checkmark$ & $\checkmark$ & & PSO & $\checkmark$ & $\begin{array}{l}\text { The flexural capacity of the } \\
\text { optimized sections was improved } \\
\text { by up to } 65 \% \text { compared to } \\
\text { conventional CFS sections. }\end{array}$ \\
\hline
\end{tabular}


Table 1. Cont.

\begin{tabular}{|c|c|c|c|c|c|c|c|c|c|c|}
\hline \multirow[b]{2}{*}{ Researcher } & \multirow[b]{2}{*}{ Year } & \multirow[b]{2}{*}{ Element Type } & \multirow[b]{2}{*}{$\begin{array}{c}\text { Fixed } \\
\text { Amount of } \\
\text { Material }\end{array}$} & \multirow[b]{2}{*}{$\begin{array}{c}\text { Design } \\
\text { Specification }\end{array}$} & \multicolumn{3}{|c|}{ Constraints Imposed } & \multirow[b]{2}{*}{$\begin{array}{l}\text { Optimization } \\
\text { Method }\end{array}$} & \multirow[b]{2}{*}{$\begin{array}{l}\text { Validated by } \\
\text { FEA }\end{array}$} & \multirow[b]{2}{*}{ Conclusions } \\
\hline & & & & & $\begin{array}{c}\text { Geometric } \\
\text { Requirement }\end{array}$ & $\begin{array}{l}\text { Practical \& } \\
\text { Manufactur- } \\
\text { ing } \\
\text { Constraints }\end{array}$ & $\begin{array}{l}\text { Assembly \& } \\
\text { End-Use } \\
\text { Constraints }\end{array}$ & & & \\
\hline Tian and Lu [138] & 2004 & Columns & & BS 5950-5 & $\checkmark$ & & & $\begin{array}{l}\text { Sequential } \\
\text { Quadratic } \\
\text { Programming } \\
\text { (SQP) }\end{array}$ & & $\begin{array}{c}\text { The optimal C-section showed a } \\
\text { better performance. }\end{array}$ \\
\hline Lee et al. [118] & 2005 & Beams & & AISI S100 & $\checkmark$ & & & MGA & & $\begin{array}{l}\text { MGAs showed excellent } \\
\text { performance in seeking the } \\
\text { minimum weight design of } \\
\text { cold-formed steel channel beams. }\end{array}$ \\
\hline Liu et al. [137] & 2004 & Columns & $\checkmark$ & AISI S100 & $\checkmark$ & & & $\begin{array}{l}\text { A global } \\
\text { optimization } \\
\text { approach }\end{array}$ & & $\begin{array}{l}\text { Optimized CFS cross-sectional } \\
\text { shapes showed much higher } \\
\text { strength than commonly used } \\
\text { shapes (up to 300\% improvement) }\end{array}$ \\
\hline Sharafi et al. [114] & 2014 & $\begin{array}{l}\text { Beam-column } \\
\text { members }\end{array}$ & & AS/NZ 4600 & $\checkmark$ & & & $\begin{array}{l}\text { Graph theory } \\
\text { and ACO } \\
\text { algorithm }\end{array}$ & & $\begin{array}{c}\text { A new methodology was presented } \\
\text { for shape and sizing optimizations } \\
\text { of CFS sections by using the graph } \\
\text { theory approach. }\end{array}$ \\
\hline $\begin{array}{l}\text { Kripka and Chamberlain } \\
\text { Pravia [136] }\end{array}$ & 2013 & Columns & & AISI 2007 [142] & $\checkmark$ & & & SA & & $\begin{array}{c}\text { The presence of lips considerably } \\
\text { increased its efficiency, generating } \\
\text { an additional reduction in the total } \\
\text { amount of material (approximately } \\
15 \% \text { ). }\end{array}$ \\
\hline Parastesh et al. [46] & 2021 & $\begin{array}{l}\text { Anti-symmetric } \\
\text { beam-columns } \\
\text { members }\end{array}$ & $\checkmark$ & AISI S100 & $\checkmark$ & $\checkmark$ & $\checkmark$ & GA & $\checkmark$ & $\begin{array}{l}\text { The strength of beam-column } \\
\text { members was significantly } \\
\text { increased by } 62 \%, 92 \% \text {, and } 188 \% \\
\text { for the short, medium, and long } \\
\text { length elements, respectively, using } \\
\text { the adopted optimization process. }\end{array}$ \\
\hline
\end{tabular}




\subsubsection{Optimization of CFS Columns}

A lot of optimization work has also been carried out on CFS columns. Leng et al. [113] performed an unconstrained shape optimization to maximize the compressive strength of an open CFS channel section. However, many of the solutions were highly unconventional and had potential limitations both concerning end-use and cost of manufacturing [113]. In a later study, Leng et al. [112] incorporated the end-use and manufacturing constraints into the shape optimization to offer more practical design solutions. The SA algorithm was adopted to optimize the CFS columns with maximum axial capacity, and the capacity of the optimized cross-sections was found to be only marginally decreased (less than 10\%) from the earlier unconstrained optimized solutions [77].

Madeira et al. [115] investigated the optimal design of CFS columns to maximize the local-global interactive buckling strength and the distortional buckling strength. Dias and Mahendran [124] conducted an optimization study of the CFS wall studs using SA and GA, incorporating sheathing restraints into their analysis. In another relevant study, Moharrami et al. [122] used a combination of GA and GDO to investigate the optimal folding of open CFS cross-sections under compression. Gilbert et al. [132] presented and applied a self-shape optimization method to maximize the strength of singly symmetric open CFS channel columns.

\subsubsection{Optimization of CFS Beam-Column Members}

As opposed to the existing large body of knowledge on optimization of CFS members under pure bending or pure compression, only a few studies are available that investigated the optimum design of CFS beam-column elements subjected to various combinations of bending and compression. Parastesh et al. [50] performed a constrained optimization of symmetrical CFS beam-column members with different lengths under different loading combinations. They [46] also performed a constrained optimization of non-symmetrical CFS beam-column members. Mojtabaei et al. [20] conducted a similar study and took the built-up beam-column members into account.

\subsubsection{Structural System-Level Optimization}

Phan et al. [98] optimized the CFS portal frames using GA to improve their structural performance. Compared to the standard lipped channel sections, the optimized CFS components demonstrated considerable strength improvements (up to 84\%) [98]. The proposed coupled framework using the more efficient CFS cross-sectional shapes optimized for generic applications was shown to be more cost-effective (using up to $20 \%$ less structural material) when compared to the conventional optimization using standard cross-sections [98].

\section{Thermal Performance and Energy Efficiency of CFS Structures}

Energy use is an important aspect of long-term sustainability. The operational period consumes 80 to $85 \%$ of the total energy use during a building's life cycle [3]. For a residential building, energy is mainly used for heating in winter and cooling in summer. According to Moradibistouni et al. [143], heating is the principal energy consumption in the houses in New Zealand and in Australia, accounting for nearly a third of the total energy use. The burning of fossil fuels and the usage of electricity and water in buildings account for the majority of carbon emissions [144]. It is critical to boost operational energy efficiency in order to reduce the environmental impact of climate change [145].

The term "thermal performance" in this paper refers to a building's ability to adapt to changes in the outside environment while preserving internal thermal comfort. These conditions are attained with the least amount of energy used for heating and cooling. The building's energy efficiency implies using less amount of energy to maintain the same room temperature. In this perspective, the thermal performance of CFS structures can be optimized by minimizing the thermal bridges and lowering thermal transmittance or 
increasing the thermal resistance of the building envelopes [16,146]. The building envelope has long been seen as the first line of defense towards achieving high-energy-efficient buildings [147,148]. Insulation materials are commonly used in the building envelope to reduce heat loss [149].

\subsection{Introduction to Thermal Bridge}

Although CFS construction offers various benefits and high potential in pursuing sustainability, it may present some problems regarding its thermal performance because of the high thermal conductivity of the steel $[10,18,48,146]$. Steel elements installed in the building envelope can form thermal bridges, where heat and energy are transferred from one side of the member to the other [150]. Thermal bridges can significantly increase the energy demand due to heat dissipation and adversely affect the overall embodied energy in the structure [151-154]. Roque and Santos [18] demonstrated that neglecting the effect of heat transfer in steel structures can overestimate the thermal resistance by up to $50 \%$.

If not appropriately addressed, thermal bridges originated by the steel studs can seriously lower the energy efficiency of any CFS building and increase the energy consumption and associated costs during its operational stage [18]. Except for the increased energy consumption, the localized heat losses may also influence the buildings' hygrothermal performance, leading to construction pathologies, degradation of the building elements, reduction of indoor air quality, and surface and interstitial condensation phenomena [17]. Furthermore, poor thermal performance may cause condensation, which can cause discomfort to the occupants [150]. These drawbacks are particularly critical in regions with a large range of variations in the daily temperature [16]. The National Association of Steel-framed Housing Incorporated (NASH) in New Zealand has planned to conduct a research programme on delivering the CFS building that can achieve the performance with international best practice [155]. The New Zealand homes with international best practices are aimed to perform better, use less energy and provide higher levels of comfort while significantly reducing the costs associated with cold, wet, under-heated and unhealthy homes [155].

\subsection{Different Methods Used to Estimate the Thermal Resistance/Transmittance}

A building component may have homogeneous or heterogeneous layers. An accurate estimation of the thermal transmittance ( $U$-value) or thermal resistance ( $R$-value) of the building envelope element is fundamental for a reliable estimation of their thermal performance and energy efficiency [156]. There are several approaches to obtain $U$-values or $R$-values of building elements: analytical, numerical, and experimental [157].

\subsubsection{Analytical Approach}

Analytical formulas are considered to be the most straightforward approach among these three methods [158]. The generated heat flow transfer is one-dimensional when the building element is made up of $n$ homogeneous layers $(j)$ that are perpendicular to the heat flow [159]. According to ISO 6946 [159], the total thermal resistance shall be calculated as

$$
R_{t o t}=R_{s i}+\sum_{j=1}^{n} R_{j}+R_{s e}
$$

where, $R_{s i}$ and $R_{s e}$ denotes the theoretical internal and external surface thermal resistances, respectively $\left(\mathrm{m}^{2} \cdot \mathrm{K} / \mathrm{W}\right)$, and $R_{j}$ represents the thermal resistance of each homogeneous layer $j$.

The thermal transmittance ( $U$-values) is determined by

$$
U=\frac{1}{R_{t o t}}
$$

When the building component contains heterogeneous layers, the heat flow becomes two-dimensional instead of one-dimensional. Several methods that can be used to estimate 
the $R$-value of building elements containing heterogeneous layers have been found in the existing body of literature.

In the ISO 6946 Combined Method [159], the total thermal resistance of a component is computed by averaging its upper and lower limits. The upper limit of the total thermal resistance $\left(R_{\text {upper }}\right)$ is evaluated by using the parallel path method. The flanges and the lips are not considered in this method. Only the web of the stud and the thickness of the web stud are considered. Figure 5a shows the two main paths and Figure 5b illustrates these equivalent parallel path circuits for the two paths.

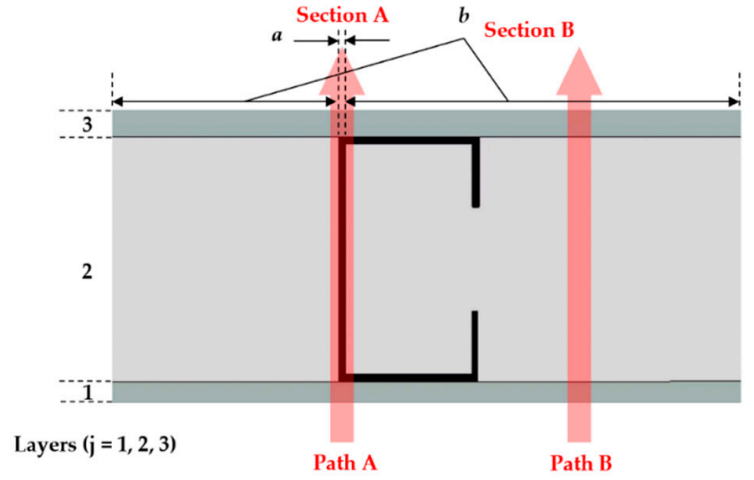

(a)

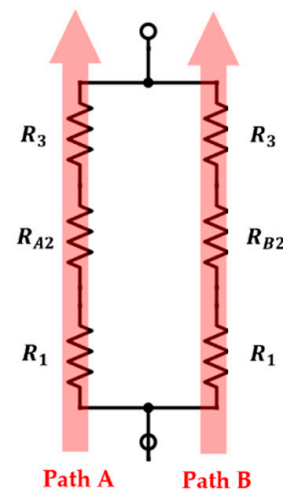

(b)

Figure 5. (a) Cross-section of the CFS framed wall with two main paths; (b) Equivalent circuit using the parallel path method.

The upper limit is given by,

$$
\frac{1}{R_{\text {upper }}}=\frac{f_{A}}{R_{\text {tot } ; A}}+\frac{f_{B}}{R_{t o t ; B}}
$$

where, $f_{A}$ and $f_{B}$ denotes the fractional areas of Sections A and B, respectively, $R_{t o t ; A}$ and $R_{t o t ; B}$ are the total thermal resistances of each path.

The lower limit of the total thermal resistance $\left(R_{\text {lower }}\right)$ is evaluated by using the isothermal planes method. Figure 6a illustrates an example of a CFS framed wall with three layers and two sections. Similarly, only the web of the steel stud is taken into consideration in the heat transfer calculation. Figure $6 \mathrm{~b}$ illustrates the equivalent series-parallel circuit.

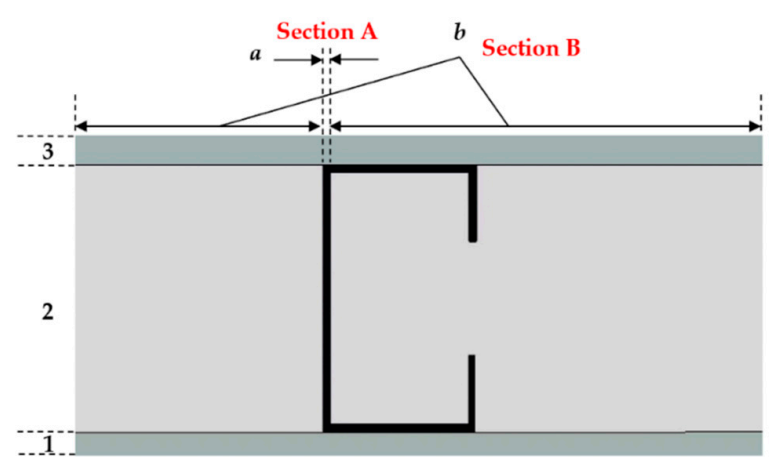

Layers $(\mathrm{j}=1,2,3)$

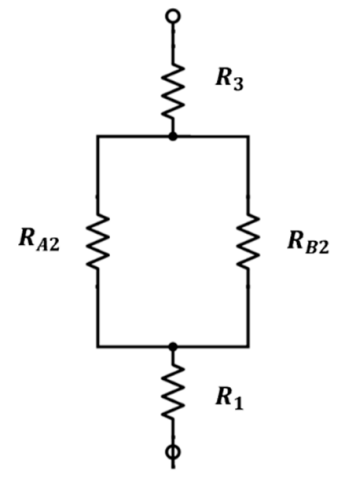

(b)

Figure 6. (a) Cross-section of CFS framed wall with three layers and two sections; (b) Equivalent series-parallel circuit. 
The equivalent thermal resistance for the thermally nonhomogeneous layer $2\left(R_{2}\right)$ is calculated using the parallel path method, given in Equation (20)

$$
\frac{1}{R_{2}}=\frac{f_{A}}{R_{A 2}}+\frac{f_{B}}{R_{B 2}}
$$

After that, the lower limit of the total thermal resistance can be computed as a sum of the series resistances, given in Equation (21)

$$
R_{\text {lower }}=R_{s i}+R_{1}+R_{2}+R_{3}+R_{s e}
$$

The total thermal resistance is given by

$$
R_{\text {tot }}=\frac{R_{\text {upper }}+R_{\text {lower }}}{2}
$$

Gorgolewski [158] adapted the ISO 6946 Combined Method to a more reliable analytical $U$-value calculation approach for CFS buildings. The same calculation method described in ISO 6946 is used to obtain the upper and lower bounds of the thermal resistance, but Gorgolewski [158] adopted different weights for the upper and lower resistance values to compute the total resistance by considering a factor $p$, which ranges from 0 to 1 . The total $R$-value is given by Equation (23),

$$
R_{\text {tot }}=p R_{\text {upper }}+(1-p) R_{\text {lower }}
$$

The ASHRAE Zone Method [160] was one of the earliest developed analytical simplified methods for calculating the $R$-value of a CFS framed wall. It is an improvement on the parallel path method. Rather than just considering the web thickness, this method considers a larger zone of impact of the metal thermal bridge within the wall (the lips are still not ignored) [160]. As shown in Figure 7, Section W is determined by the width of the steel thermal bridge impact zone, and the remaining portion of the wall is Section CAV.

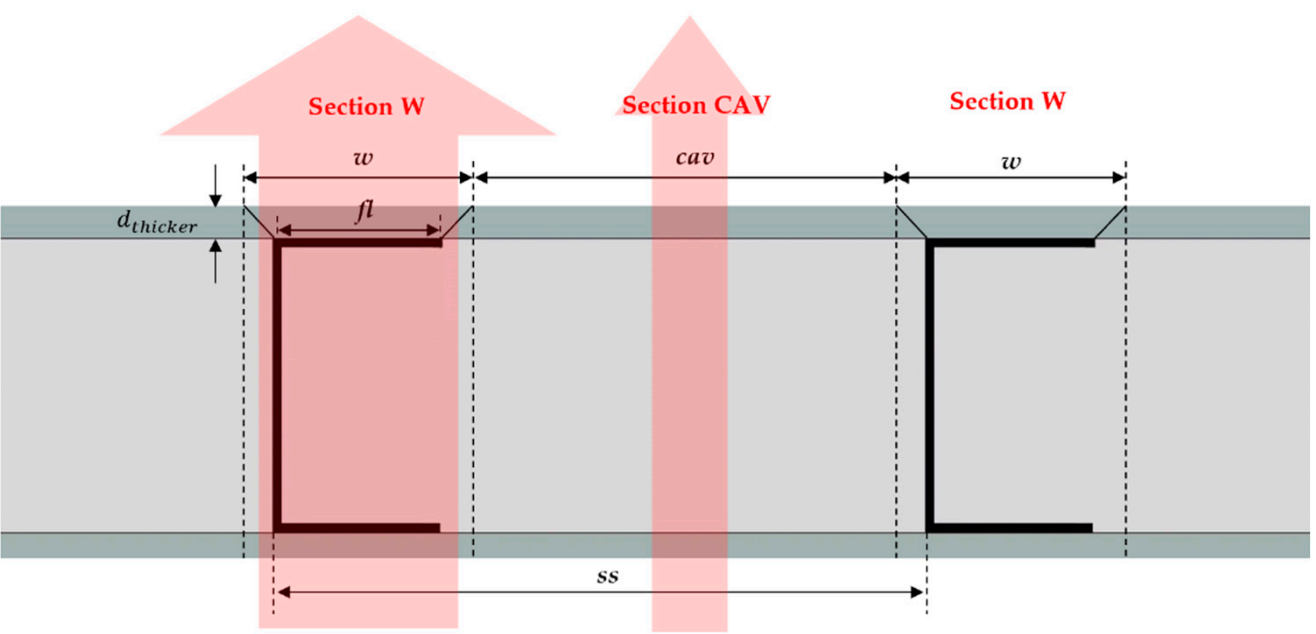

Figure 7. Section $\mathrm{W}$ and Section CAV in the ASHRAE Zone method.

The length of Section $W, w$, shall be determined by Equation (24), where $z f$ is the zone factor and $d_{\text {thicker }}$ is the thickness of the thicker sheathing side.

$$
w=f l+z f d_{\text {thicker }}
$$

The thermal resistance values are computed and then combined using the parallel path method for both paths. Figure 8 is a schematic illustration of the ASHRAE method. 


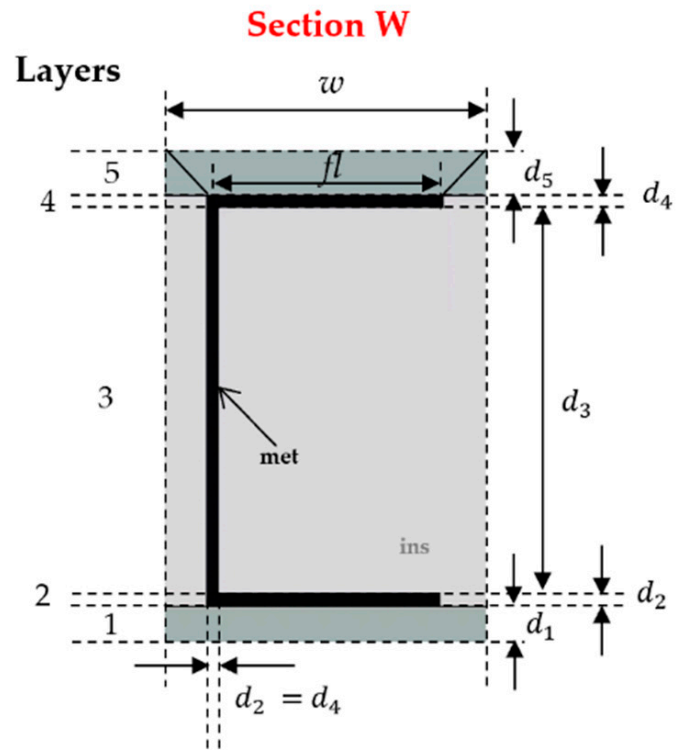

(a)

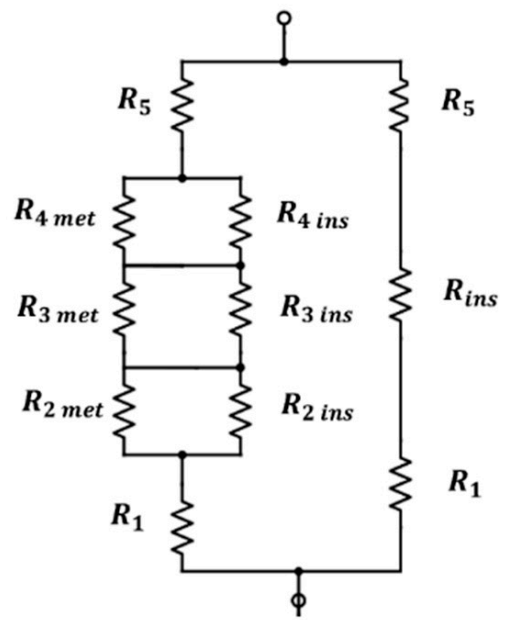

(b)

Figure 8. (a) Cross section of Section W; (b) Equivalent series-parallel circuit.

\subsubsection{Numerical Approach}

Numerical simulations can be performed with simple two-dimensional (2D) models or more complex three-dimensional (3D) models. One of the advantages of the numerical approach is that a quick comparison between several configurations of building components is allowed [156]. However, a specific software tool or skills may be required, and the employed models should be validated using measurements or at least verified by comparison with benchmark data to ensure that the obtained results are reliable [156].

\subsubsection{Experimental Approach}

The in situ or laboratory investigations can be crucial for validating numerical and analytical methods [161]. Laboratory measurements have the advantages of well-controlled ambient conditions, geometries, setups, and materials but can be very time-consuming and costly [161].

\subsection{Existing Studies on the Thermal Performance of CFS Structures}

The thermal bridges formed by the accelerated use of steel have motivated many researchers to put efforts into researching in this field, analyzing thermal performance [150,162], and its improvement [163-165] or mitigating thermal bridges $[48,166]$, the importance of flanking thermal losses [17], the importance of the size and shape of steel studs on the thermal performance [1], numerical simulations of CFS framed walls [146] and CFS buildings [153], development of analytical methods [156,158] and in situ measurement methods $[161,167]$ to estimate thermal transmittance, comparisons between different methods $[156,166]$, thermal insulation $[18,157,168,169]$, the interaction of thermal and sound insulation [19], and thermal performance and energy efficiency [170-172]. Table 2 summarizes the important research works performed over the last two decades on the thermal performance of CFS structures. 
Table 2. Summary of the important research papers analyzing the thermal performance of CFS structures.

\begin{tabular}{|c|c|c|c|c|}
\hline Researcher & Year & Topic & $\begin{array}{c}\text { Structural } \\
\text { Member/Building } \\
\text { System }\end{array}$ & Observations \\
\hline $\begin{array}{c}\text { Santos and } \\
\text { Poologanathan [1] }\end{array}$ & 2021 & $\begin{array}{l}\text { Importance of stud flanges } \\
\text { size and shape on the } \\
\text { thermal performance of } \\
\text { CFS framed walls }\end{array}$ & structural member & $\begin{array}{l}\text { The } R \text {-value decreases when } \\
\text { increasing the flange length and steel } \\
\text { stud's thickness, and a small flange } \\
\text { indentation size can result in a } \\
\text { considerable increase in } R \text {-value }\end{array}$ \\
\hline Martins et al. [48] & 2015 & $\begin{array}{c}\text { A parametric study on } \\
\text { thermal bridges mitigation } \\
\text { strategies }\end{array}$ & structural member & $\begin{array}{l}\text { Compared to the reference case, } \\
\text { implementing the mitigation } \\
\text { strategies can reduce the } U \text {-value by } \\
8.3 \% \text {. Optimization of the insulation } \\
\text { layers, such as applying new } \\
\text { insulation materials and combing with } \\
\text { the mitigation approaches, led to a } \\
\text { further decrease of } 68 \% \text {. }\end{array}$ \\
\hline Santos et al. [17] & 2013 & $\begin{array}{l}\text { Thermal performance of } \\
\text { CFS framed wall: The } \\
\text { importance of flanking } \\
\text { thermal losses }\end{array}$ & structural member & $\begin{array}{l}\text { The calculated heat flux fluctuated } \\
\text { from } 222 \% \text { to }+50 \% \text { for external and } \\
\text { internal surfaces, respectively, when } \\
\text { losses through flank were assumed } \\
\text { zero as a reference case, thermal } \\
\text { conductivity was equal to } \\
0.30 \mathrm{~W} /\left(\mathrm{m}^{2} \mathrm{~K}\right) \text {. }\end{array}$ \\
\hline Kempton et al. [166] & 2021 & $\begin{array}{l}\text { Evaluation of thermal } \\
\text { bridging mitigation } \\
\text { techniques and impact of } \\
\text { calculation methods for } \\
\text { CFS frame external wall } \\
\text { systems }\end{array}$ & structural member & $\begin{array}{l}\text { NZS } 4214 \text { method showed good } \\
\text { applicability for wall assemblies with } \\
\text { lower } R \text {-values. The best way to } \\
\text { minimise thermal bridging effects was } \\
\text { to apply outside frame insulation and } \\
\text { high resistance claddings. }\end{array}$ \\
\hline $\begin{array}{c}\text { Kapoor and } \\
\text { Peterman [150] }\end{array}$ & 2021 & $\begin{array}{l}\text { Quantification and } \\
\text { prediction of the thermal } \\
\text { performance of CFS wall } \\
\text { assemblies }\end{array}$ & structural member & $\begin{array}{l}\text { The results showed that increasing } \\
\text { CFS member thickness increased the } \\
\text { overall and component level heat flow } \\
\text { through the assembly while the stud } \\
\text { depth had negligible impact. CFS } \\
\text { member spacing was nonlinearly } \\
\text { correlated with heat flow. Adding } \\
\text { continuous external insulation outside } \\
\text { the stud cavity improved thermal } \\
\text { performance and uniformly reduced } \\
\text { the heat flow through studs } \\
\text { and tracks. }\end{array}$ \\
\hline $\begin{array}{l}\text { Roque and } \\
\text { Santos [18] }\end{array}$ & 2017 & $\begin{array}{l}\text { Effectiveness of thermal } \\
\text { insulation in CFS framed } \\
\text { walls concerning its } \\
\text { position }\end{array}$ & structural member & $\begin{array}{l}\text { A very large fluctuation was observed } \\
\text { in the results. Applying thermal } \\
\text { insulation outside the steel frame } \\
\text { could maximize its performance. }\end{array}$ \\
\hline Roque et al. [19] & 2019 & $\begin{array}{l}\text { Thermal and sound } \\
\text { insulation of CFS-framed } \\
\text { façade walls }\end{array}$ & structural member & $\begin{array}{l}\text { By changing the frame's type and } \\
\text { position in the wall, the difference in } \\
\text { the } U \text {-value can reach } 82 \% \text {. The steel } \\
\text { frame also has an impact on the sound } \\
\text { insulation performance of CFS } \\
\text { framed walls }\end{array}$ \\
\hline
\end{tabular}


Table 2. Cont.

\begin{tabular}{|c|c|c|c|c|}
\hline Researcher & Year & Topic & $\begin{array}{c}\text { Structural } \\
\text { Member/Building } \\
\text { System }\end{array}$ & Observations \\
\hline $\begin{array}{c}\text { Lohmann and } \\
\text { Santos [170] }\end{array}$ & 2020 & $\begin{array}{l}\text { Trombe wall thermal } \\
\text { behavior and energy } \\
\text { efficiency of a CFS frame } \\
\text { compartment: } \\
\text { experimental and } \\
\text { numerical assessments }\end{array}$ & structural member & $\begin{array}{c}\text { The Trombe wall device could } \\
\text { significantly improve the thermal } \\
\text { behavior of a CFS frame compartment } \\
\text { and reduce heating energy } \\
\text { consumption if it was adequately } \\
\text { designed and controlled to mitigate } \\
\text { nocturnal heat losses. }\end{array}$ \\
\hline Lupan et al. [163] & 2016 & $\begin{array}{l}\text { Improving the thermal } \\
\text { performance of the wall } \\
\text { panels using slotted steel } \\
\text { stud framing }\end{array}$ & structural member & $\begin{array}{l}\text { A correlation was found between the } \\
\text { perforated geometry of steel profiles } \\
\text { and the amount of heat flow passing } \\
\text { the element. The energy efficiency of } \\
\text { the wall rose with the decrease of } \\
\text { distance between perforation both } \\
\text { vertically and horizontally; location } \\
\text { perforations to the heart profile; } \\
\text { decreased of thickness profile; } \\
\text { increasing the number of rows of } \\
\text { holes and their length; increasing the } \\
\text { dimension of perforation. }\end{array}$ \\
\hline Santos et al. [146] & 2019 & $\begin{array}{l}\text { A parametric study on the } \\
\text { thermal transmittance of } \\
\text { internal partition and } \\
\text { external facade CFS framed } \\
\text { walls }\end{array}$ & structural member & $\begin{array}{c}\text { The numerical simulation of a CFS } \\
\text { frame interior partition with thermal } \\
\text { break strips indicated a } 24 \% \\
U \text {-value reduction. }\end{array}$ \\
\hline
\end{tabular}

Analytical methods to estimate the thermal transmittance of CFS

Santos et al. [156]

2020

framed walls: calculation procedures review and accuracy comparison

According to the obtained results, the best accuracy performance was found in the Modified Zone Method. In comparison, the worst was found in the Gorgolewski Method 2.

The results showed that the Representative Points Method was

Two new methods for the in situ measurement of the overall thermal transmittance of CFS framed walls structural member always accurate while the error of the Weighted Area Method did not exceed $2 \%$ for the cold frame and $5 \%$ for hybrid frame walls.

When considering metal frames in the simulation, the thermal peak load increased by approximately $10 \%$ compared to the reference case.

The heterogeneity of materials and the high frequency of metal studs may overestimate thermal resistance using available technical data from manufacturers.

The study revealed that for the same level of thermal insulation, the environmental impact of the recycled-PET thermal wadding-based system was smaller than that of the Mineral Wool (MW)-based system. building system structural member
A case study on the

Buzatu et al. [171] 2020 thermal performance and energy efficiency of CFS buildings 
Table 2. Cont.

\begin{tabular}{|c|c|c|c|c|}
\hline Researcher & Year & Topic & $\begin{array}{c}\text { Structural } \\
\text { Member/Building } \\
\text { System }\end{array}$ & Observations \\
\hline Santos et al. [157] & 2019 & $\begin{array}{l}\text { Thermal transmittance of } \\
\text { CFS framed walls: } \\
\text { Experimental versus } \\
\text { numerical and analytical } \\
\text { approaches }\end{array}$ & structural member & $\begin{array}{l}\text { A good agreement was found between } \\
\text { the results of the 2D FEM and the } \\
\text { analytical ISO } 6946 \text { approaches for the } \\
\text { CFS framed wall with only vertical } \\
\text { steel studs. }\end{array}$ \\
\hline Gorgolewski [158] & 2007 & $\begin{array}{l}\text { Developing a simplified } \\
\text { method of calculating } \\
U \text {-values in CFS framing }\end{array}$ & structural member & $\begin{array}{l}\text { A new method is proposed, and it was } \\
\text { found that with the proposed method, } \\
\text { the mean error of prediction } \\
\text { compared with finite element } \\
\text { modeling is less than } 3 \% \text {, with a } \\
\text { maximum error of } 8 \% \text { for a range of } \\
52 \text { assessed constructions. }\end{array}$ \\
\hline $\begin{array}{l}\text { Santos and } \\
\text { Ribeiro [165] }\end{array}$ & 2021 & $\begin{array}{l}\text { Thermal performance of } \\
\text { double-pane CFS framed } \\
\text { walls with and without a } \\
\text { reflective foil }\end{array}$ & structural member & $\begin{array}{l}\text { Using a reflective foil was a very } \\
\text { effective way to increase the thermal } \\
\text { resistance of double pane CFS walls } \\
\text { without increasing the wall thickness } \\
\text { and weight; the maximum } \\
\text { improvement was around a } 21 \% \\
\text { increase in the } R \text {-value. }\end{array}$ \\
\hline $\begin{array}{c}\text { Steau and } \\
\text { Mahendran [168] }\end{array}$ & 2021 & $\begin{array}{l}\text { Elevated temperature } \\
\text { thermal properties of fire } \\
\text { protective boards and } \\
\text { insulation materials for } \\
\text { CFS framed systems }\end{array}$ & structural member & $\begin{array}{l}\text { Several materials such as gypsum } \\
\text { plasterboards, calcium silicate boards, } \\
\text { perlite boards, and rock wool fibre } \\
\text { insulation have been identified as } \\
\text { suitable for use in CFS framing } \\
\text { systems because of their high specific } \\
\text { heat, low thermal conductivity, } \\
\text { reduced mass loss, and low } \\
\text { bulk density. }\end{array}$ \\
\hline $\begin{array}{c}\text { Beggas and } \\
\text { Zeghiche [164] }\end{array}$ & 2013 & $\begin{array}{l}\text { The use of slag stone } \\
\text { concrete to improve the } \\
\text { thermal performance of } \\
\text { CFS buildings }\end{array}$ & building system & $\begin{array}{l}\text { The use of slag stone concrete as a } \\
\text { filler material for light steel structures } \\
\text { reduced the heat loss or gain through } \\
\text { these elements compared to ordinary } \\
\text { concrete made with } \\
\text { conventional aggregate. }\end{array}$ \\
\hline Santos et al. [162] & 2011 & $\begin{array}{l}\text { Parametric analysis of the } \\
\text { thermal performance of } \\
\text { CFS residential buildings }\end{array}$ & building system & $\begin{array}{l}\text { The parameters with more influence } \\
\text { during the cooling season were the } \\
\text { overhangs and the ventilation. An } \\
\text { optimum building envelope and the } \\
\text { operational solution were specified for } \\
\text { average Csb climate conditions. }\end{array}$ \\
\hline Li et al. [172] & 2017 & $\begin{array}{l}\text { Thermal and energy } \\
\text { performance of a } \\
\text { steel-bamboo composite } \\
\text { wall structure }\end{array}$ & structural member & $\begin{array}{l}\text { The results showed that the } \\
\text { steel-bamboo wall had a high thermal } \\
\text { performance with an improvement of } \\
\text { U value by up to } 26.1 \%-48.4 \% \text {, } \\
\text { indicating a lower heating demand } \\
\text { than common wall structures } \\
\text { in winter. }\end{array}$ \\
\hline
\end{tabular}

Because of the considerable number and the significantly reduced thickness of CFS profiles, along with the strong contrast between its thermal conductivity and the insulation materials, it is difficult to predict the thermal performance of CFS structures [48,156-159]. According to De Angelis and Serra [169], assessing the thermal performance of CFS buildings needs more complicated and extensive research than masonry structures. Most thermal 
analysis studies simplify the problem by assuming one-dimensional heat fluxes through the envelope [173].

\subsubsection{Parametric Studies}

A parametric analysis was performed by Santos et al. [162] to assess the thermal performance of CFS residential buildings. They investigated the impact of a number of variables, including ventilation rate, thermal insulation level, shade overhangs, window shading devices, and window glazing. Kapoor and Peterman [150] used 3D steady-state thermal analysis to investigate the impact of thickness, depth, and spacing of steel studs on the thermal behavior of CFS wall assemblies. Similarly, Santos et al. [146] evaluated several parameters and their influences on the thermal transmittance of the wall. The parameters included the thickness of steel studs, studs spacing, thickness and material of thermal break strips, inner sheathings panels arrangement, and thickness of EPS external thermal insulation composite system (ETICS) [146]. More recently, Samiee et al. [174] investigated the effect of various parameters on the thermal and structural behavior of CFS framed walls at high temperatures.

Santos et al. [17] analyzed the effect of flanking thermal losses on the thermal performance of a CFS framed wall, concluding that flanking heat loss must be taken into account. The influence of steel stud size and shape on the thermal performance of CFS members was studied by Santos and Poologanathan [1]. They found that the $R$-value decreased as the flange length and steel stud thickness increased [1].

\subsubsection{Thermal Transmittance Estimation Methods}

Santos et al. [157] evaluated the $U$-value of three distinct CFS framed walls using the Heat Flow Meter technique, 2D and 3D FE simulations, and the ASHRAE zone method, respectively. For the CFS wall with only vertical steel studs, they found good agreement between the results of the 2D FEM and the analytical ISO 6946 method [157].

Santos et al. [156] estimated the $U$-values of 80 different CFS framed wall models using six analytical methods. The analytically determined $U$-values were compared to numerically obtained $U$-values from THERM [156], a 2D FE program. All of the investigated analytical methods performed well in terms of their accuracy, and the Modified Zone Method was found to be the most suitable method [156].

\subsubsection{Thermal Bridge Mitigation Strategies}

Many researchers assessed mitigation methods of the thermal bridge in CFS structures. The ones most found in the literature were continuous external insulation $[16,150,153,166]$, the use of thermal break strips [16,146], and the use of slotted steel studs $[16,48,163]$. Martins et al. [48] discussed how to optimize a CFS framed wall model through minimizing thermal bridges. Implementing those mitigation strategies reduced the thermal transmittance by $8.3 \%$ [48].

The most effective way to reduce energy usage and hence greenhouse gas emissions is to utilize proper insulation materials $[175,176]$. Mineral wool is the most common thermal insulation material used within the steel frame [177]. Using an ETICS with expanded polystyrene (EPS) is also relatively common [10].

Unlike traditional construction, the thermal performance of CFS buildings is highly dependent on the thermal insulation used in such buildings [16,171]. Roque and Santos [18] showed that the location of thermal insulation in CFS framed facade walls has a huge impact on its thermal performance. Moreover, they indicated that if more insulation materials are utilized to lower the need for operational energy, the trade-off between embodied and operational energy must be taken into account [18,178]. Moradibistouni et al. [143] used a life cycle assessment approach to find the most effective level of insulation with a focus on the effect of the national energy profile in New Zealand. Some researchers investigated the optimization of insulation layers, such as finding the optimal thickness of insulation 
materials [143,175], making use of new insulation materials [48], or innovative insulation systems [179].

The use of thermal break on the external side of the CFS studs also allows the system to meet the appropriate energy performance standards [16]. Santos et al. [146] calculated the $U$-value of a CFS framed partition wall with thermal break strips using numerical simulation and discovered a decrease of $24 \%$ compared to the reference example.

An alternative solution to mitigate thermal bridges is using slotted studs, in which staggered longitudinal penetrations are placed into the web of the stud during production. The slots allow the thermal energy to travel a longer journey, reducing the heat or cold that reaches the flange on the stud's opposite side [16]. Because of the additional manufacturing costs and lowered structural load capacity caused due to the presence of web penetrations, this solution has gained limited application [16].

\subsubsection{Interaction between the Thermal and Sound Insulation Performance}

Roque et al. [19] found that the steel frame can have a significant impact on the sound insulation performance of CFS framed walls. Khan and Bhattacharjee [180] studied the interaction between the building envelope's thermal and noise insulation performance. The results obtained show the adverse effect of independent thermal and noise insulation optimization on the building envelope walls' overall noise insulation and thermal performances.

\subsubsection{Passive Solar Design}

A Trombe wall (TW) is a passive solar device that can be installed on the facade of a building to absorb solar heat, heating, and cooling internal rooms while enabling natural ventilation to improve thermal and energy performances [170]. Lohmann and Santos [170] investigated a Trombe wall's thermal behavior and energy efficiency in a CFS frame using in situ measurements and numerical simulations. According to their research, the Trombe wall device might dramatically improve the thermal behavior of a CFS compartment while also lowering the heating energy consumption. For example, a $27 \%$ reduction in heating energy was found for an office $18^{\circ} \mathrm{C}$ set-point due to the TW device [170].

\section{Summary and Recommendations}

CFS construction is widely perceived as a vital contributor to sustainability and green construction. The optimization of CFS members is a critical research subject, given the current increase in CFS use, the appearance of more complicated cross-sectional shapes, continuous manufacturing improvements, and the ever-increasingly important quest for economical and sustainable building solutions. The application of CFS structures has significantly increased over the last few years. As a large proportion of the total energy used in a building is consumed by heating and cooling, the thermal bridge formed by the high thermal conductivity of steel in CFS members has also attracted many researchers' interests. Combining structural and thermal performances could provide insightful advice to engineers, architects, and other building professionals to conduct sustainable design for CFS buildings. This paper reviews the existing studies on the structural optimization of CFS sections and the thermal performance of CFS structures. In total, over 160 articles were critically reviewed, which were published in the literature from the year of 1997 to 2021.

It is found that a large number of studies have been conducted on how to optimize the cross-section of CFS for better structural behavior. In order to get more practical solutions, more and more constraints are considered in the optimization process. More recently, the CFS sections' loading conditions have changed from pure bending/compression to combined loading scenarios, and different optimization techniques have been applied during the optimization process. GA is found to be the most popular stochastic search algorithms used in the context of CFS structures. However, the study on structural systemlevel optimization is rare. 
The prediction and quantification of the thermal performance of CFS structures are generally agreed to be challenging. Applying appropriate insulation is always considered as the most effective way to reduce the thermal bridge and energy consumption. Except for using insulation materials, the potential of optimizing the cross-sectional shape of CFS and CFS systems to further improve their thermal performance has been found in the existing literature.

For future research, the effort could be put into developing combined strategies to improve the thermal performance of CFS structures. For instance, applying insulation materials or installing new systems that take advantage of solar energy could be combined with optimizing the cross-sectional shape of CFS members to achieve a higher level of thermal resistance. Besides, more system-level optimization studies could be conducted rather than just research on the CFS members. Although studies can be found regarding the optimization of CFS members for better structural behavior, or thermal performance improvement of CFS framed walls, the research on optimization from both perspectives at the same time is not widespread. Therefore, it is also recommended that future research be focused on optimizing CFS structures to consider both embodied energy and operational energy to fulfill the research gap.

Author Contributions: Conceptualization, H.L., K.R., Z.F. and J.B.P.L.; methodology, H.L. and K.R.; investigation, H.L., K.R. and Z.F.; writing-original draft preparation, H.L.; writing-review and editing, H.L., K.R., Z.F. and J.B.P.L. All authors have read and agreed to the published version of the manuscript.

Funding: This research received no external funding.

Institutional Review Board Statement: Not applicable.

Informed Consent Statement: Not applicable.

Data Availability Statement: Not applicable.

Conflicts of Interest: The authors declare no conflict of interest.

\section{References}

1. Santos, P.; Poologanathan, K. The importance of stud flanges size and shape on the thermal performance of lightweight steel framed walls. Sustainability 2021, 13, 3970. [CrossRef]

2. Wang, N.; Phelan, P.E.; Harris, C.; Langevin, J.; Nelson, B.; Sawyer, K. Past visions, current trends, and future context: A review of building energy, carbon, and sustainability. Renew. Sustain. Energy Rev. 2018, 82, 976-993. [CrossRef]

3. Sharma, A.; Saxena, A.; Sethi, M.; Shree, V.; Varun. Life cycle assessment of buildings: A review. Renew. Sustain. Energy Rev. 2011, 15, 871-875. [CrossRef]

4. United Nations Environment Programme. In Proceedings of the 2020 Global Status Report for Buildings and Construction: Towards a Zero-emission, in Efficient and Resilient Buildings and Construction Sector, Nairobi, Kenya, 16 December 2020.

5. Abdellatif, M.; Al-Shamma'a, A. Review of sustainability in buildings. Sustain. Cities Soc. 2015, 14, 171-177. [CrossRef]

6. Iuorio, O.; Napolano, L.; Fiorino, L.; Landolfo, R. The environmental impacts of an innovative modular lightweight steel system: The Elissa case. J. Clean Prod. 2019, 238, 117905. [CrossRef]

7. McLaren, S.J.; Chandrakumar, C.; Dowdell, D.; Bullen, L.; Jaques, R. Application of absolute sustainability assessment to new zealand residential dwellings. IOP Conf. Ser. Earth Environ. Sci. 2020, 588, 022064. [CrossRef]

8. Womens Agenda. Available online: https://womensagenda.com.au/climate/jacinda-ardern-says-new-zealand-will-halveemissions-by-2030 / (accessed on 4 November 2021).

9. Tokazhanov, G.; Tleuken, A.; Guney, M.; Turkyilmaz, A.; Karaca, F. How is COVID-19 experience transforming sustainability requirements of residential buildings? A review. Sustainability 2020, 12, 8732. [CrossRef]

10. Soares, N.; Santos, P.; Gervásio, H.; Costa, J.J.; Simões da Silva, L. Energy efficiency and thermal performance of lightweight steel-framed (LSF) construction: A review. Renew. Sustain. Energy Rev. 2017, 78, 194-209. [CrossRef]

11. Oliveira, R.; Figueiredo, A.; Romeu, V.; Ricardo, M.S.F.A. Multi-objective optimisation of the energy performance of lightweight constructions combining evolutionary algorithms and life cycle cost. Energies 2018, 11, 1863. [CrossRef]

12. Johnston, R.P.D.; McGrath, T.; Nanukuttan, S.; Lim, J.B.P.; Soutsos, M.; Chiang, M.C.; Masood, R.; Rahman, M.A. Sustainability of cold-formed steel portal frames in developing countries in the context of life cycle assessment and life cycle costs. Structures 2018, 13, 79-87. [CrossRef]

13. Maxineasa, S.G.; Isopescu, D.N.; Baciu, I.R.; Lupu, M.L.; Dragan, T.C. Thermal analysis of a structure made by using cold formed steel sections. IOP Conf. Ser. Mater. Sci. Eng. 2020, 789, 012039. [CrossRef] 
14. Forgione, S. Uncovering Cold-Formed Steel's Sustainable Benefits: A Holistic View of Sustainability, Resiliency and Recyclability of Cfs Makes the Case for Building Greener and Long-Term Impacts of the World's most Recycled Building Material; Walls \& Ceilings: Tory, MI, USA, 2020; p. 24.

15. Harini, B.; Lingeshwaran, N.; Perumal, K.; Aravinthan, K. Sustainable design of cold formed steel. Mater. Today Proc. 2020, 33, 881-885. [CrossRef]

16. Williams, L.W. Introduction to Recent Trends in Cold-Formed Steel Construction, in Recent Trends in Cold-Formed Steel Construction; Yu, C., Ed.; Woodhead Publishing: Sawston, UK, 2016; pp. 1-35.

17. Santos, P.; Martins, C.; da Silva, L.S.; Bragança, L. Thermal performance of lightweight steel framed wall: The importance of flanking thermal losses. J. Build. Phys. 2013, 38, 81-98. [CrossRef]

18. Roque, E.; Santos, P. The effectiveness of thermal insulation in lightweight steel-framed walls with respect to its position. Buildings 2017, 7, 13. [CrossRef]

19. Roque, E.; Santos, P.; Pereira, A.C. Thermal and sound insulation of lightweight steel-framed façade walls. Sci. Technol. Built Environ. 2019, 25, 156-176. [CrossRef]

20. Mojtabaei, S.M.; Becque, J.; Hajirasouliha, I. Structural size optimization of single and built-up cold-formed steel beam-column members. J. Struct. Eng. 2021, 147, 04021030. [CrossRef]

21. Ye, J.; Hajirasouliha, I.; Becque, J.; Pilakoutas, K. Development of more efficient cold-formed steel channel sections in bending. Thin-Walled Struct. 2016, 101, 1-13. [CrossRef]

22. Boon-Kai, T.; Poi-Ngian, S.; Kueh-Beng-Hong, A. Influences of yield strength and section depth to the compression capacity of single cold-formed channel lipped. IOP Conf. Ser. Mater. Sci. Eng. 2019, 620, 012069. [CrossRef]

23. Karim, A.; Adeli, H. Global optimum design of cold-formed steel hat-shape beams. Thin-Walled Struct. 1999, 35, $275-288$. [CrossRef]

24. Schafer, B.W. Cold-formed steel structures around the world. Steel Constr. 2011, 4, 141-149. [CrossRef]

25. Lowe, D.; Roy, K.; Das, R.; Clifton, C.G.; Lim, J.B.P. Full scale experiments on splitting behaviour of concrete slabs in steel concrete composite beams with shear stud connection. Sustainability 2020, 23, 126-138. [CrossRef]

26. Roy, K.; Lau, H.H.; Huon Ting, T.C.; Masood, R.; Kumar, A.; Lim, J.B.P. Experiments and finite element modelling of screw pattern of self-drilling screw connections for high strength cold-formed steel. Thin-Walled Struct. 2019, 145, 106393. [CrossRef]

27. Lawson, R.; Way, A.; Heywood, M.; Lim, J.; Johnston, R.; Roy, K. Stability of light steel walls in compression with plasterboards on one or both sides. Proc. Inst. Civ. Eng. Struct. Build. 2019, 173, 394-412. [CrossRef]

28. Hancock, G.J. Cold-formed steel structures: Research review 2013-2014. Adv. Struct. Eng. 2016, 19, 393-408. [CrossRef]

29. McIntosh, A.; Gatheeshgar, P.; Poologanathan, K.; Gunalan, S.; Navaratnam, S.; Higgins, C. Web crippling of cold-formed carbon steel, stainless steel, and aluminium channels: Investigation and design. J. Constr. Steel Res. 2021, 179, 106538. [CrossRef]

30. Kaleeswaran, C.; Saravanakumar, R.; Vivek, D.; Elango, K.S.; Gopi, R.; Balaji, D. A study on cold formed steel compression member-a review. Mater. Today Proc. 2021, 37, 1767-1771. [CrossRef]

31. Dar, M.A.; Narayanan, S.; Rather, A.; Dar, A.; Lim, J.; Anbarasu, M.; Roy, K. Effect of angle stiffeners on the flexural strength and stiffness of cold-formed steel beams. Steel Compos. Struct. 2019, 33, 225-243.

32. Mathieson, C.; Clifton, G.C.; Lim, J.B.P. Novel pin-jointed connection for cold-formed steel trusses. J. Constr. Steel Res. 2016, 116, 173-182. [CrossRef]

33. Mathieson, C.; Roy, K.; Charles Clifton, G.; Ahmadi, A.; Lim, J.B.P. Failure mechanism and bearing capacity of cold-formed steel trusses with HRC connectors. Eng. Struct. 2019, 201, 109741. [CrossRef]

34. Roy, K.; Lim, J.B.P.; Lau, H.H.; Yong, P.M.; Clifton, G.C.; Johnston, R.P.D.; Wrzesien, A.; Mei, C.C. Collapse behaviour of a fire engineering designed single-storey cold- formed steel building in severe fires. Thin-Walled Struct. 2019, 142, 340-357. [CrossRef]

35. Bedair, O. A cost-effective design procedure for cold-formed lipped channels under uniform compression. Thin-Walled Struct. 2009, 47, 1281-1294. [CrossRef]

36. Lim, J.B.P.; Wrzesien, A.M.; Nethercot, D.A. Sustainable Applications of Cold-Formed Steel Structures: Portal Frames, in Recent Trends in Cold-Formed Steel Construction; Yu, C., Ed.; Woodhead Publishing: Sawston, UK, 2016; pp. 265-303.

37. Gatheeshgar, P.; Poologanathan, K.; Gunalan, S.; Shyha, I.; Sherlock, P.; Rajanayagam, H.; Nagaratnam, B. Development of affordable steel-framed modular buildings for emergency situations (COVID-19). Structures 2021, 31, 862-875. [CrossRef]

38. Gatheeshgar, P.; Parker, S.; Askew, K.; Poologanathan, K.; Navaratnam, S.; McIntosh, A.; Widdowfield Small, D. Flexural behaviour and design of modular construction optimised beams. Structures 2021, 32, 1048-1068. [CrossRef]

39. Suresh babu, S.; Senthil selvan, S. State of the art of cold formed steel members. Mater. Today Proc. 2021, 37, 3069-3073. [CrossRef]

40. Iuorio, O.; Napolano, L.; Fiorino, L.; Landolfo, R. Sustainability of modular lightweight steel building from design to deconstruction. In International Specialty Conference on Cold-Formed Steel Structures. Wei-Wen Yu International Specialty Conference on Cold-Formed Steel Structures 2018; St. Louis, MO, USA, 7-8 November 2018, LaBoube, R.A., Yu, W.W., Eds.; Missouri University of Science and Technology: St. Louis, MO, USA, 2018; pp. 515-528.

41. Košir, M.; Iglič, N.; Kunič, R. Optimisation of heating, cooling and lighting energy performance of modular buildings in respect to location's climatic specifics. Renew. Energy 2018, 129, 527-539. [CrossRef]

42. Ceranic, B.; Beardmore, J.; Cox, A. Rapid deployment modular building solutions and climatic adaptability: Case based study of a novel approach to thermal capacity on demand. Energ. Build. 2018, 167, 124-135. [CrossRef] 
43. Gatheeshgar, P.; Poologanathan, K.; Thamboo, J.; Roy, K.; Rossi, B.; Molkens, T.; Perera, D.; Navaratnam, S. On the fire behaviour of modular floors designed with optimised cold-formed steel joists. Structures 2021, 30, 1071-1085. [CrossRef]

44. Rehman, M.; Sakalle, R. Finite elemental analysis of industrial structure using cold formed steel. AIP Conf. Proc. 2019, 2158, 020014.

45. Magnucka-Blandzi, E.; Magnucki, K. Buckling and optimal design of cold-formed thin-walled beams: Review of selected problems. Thin-Walled Struct. 2011, 49, 554-561. [CrossRef]

46. Parastesh, H.; Mohammad Mojtabaei, S.; Taji, H.; Hajirasouliha, I.; Bagheri Sabbagh, A. Constrained optimization of antisymmetric cold-formed steel beam-column sections. Eng. Struct. 2021, 228, 111452. [CrossRef]

47. Becque, J. Optimization of cold-formed steel products: Achievements, challenges and opportunities. ce/papers 2019, 3, 211-218. [CrossRef]

48. Martins, C.; Santos, P.; da Silva, L.S. Lightweight steel-framed thermal bridges mitigation strategies: A parametric study. J. Build. Phys. 2015, 39, 342-372. [CrossRef]

49. Leng, J. Optimization Techniques for Structural Design of Cold-Formed Steel Structures. In Recent Trends in Cold-Formed Steel Construction; Yu, C., Ed.; Woodhead Publishing: Sawston, UK, 2016; pp. 129-151.

50. Parastesh, H.; Hajirasouliha, I.; Taji, H.; Bagheri Sabbagh, A. Shape optimization of cold-formed steel beam-columns with practical and manufacturing constraints. J. Constr. Steel Res. 2019, 155, 249-259. [CrossRef]

51. Bayleyegn, Y.S. Section Capacity of Cold-Formed Steel Members by the Direct Strength Method; The Johns Hopkins University: Ann Arbor, MI, USA, 2010; p. 243.

52. Davies, J.M. Recent research advances in cold-formed steel structures. J. Constr. Steel Res. 2000, 55, 267-288. [CrossRef]

53. Qadir, S.J.; Nguyen, V.B.; Hajirasouliha, I.; Cartwright, B.; English, M.A. Optimal design of cold roll formed steel channel sections under bending considering both geometry and cold work effects. Thin-Walled Struct. 2020, 157, 107020. [CrossRef]

54. Manikandan, P.; Thulasi, M. Investigation on cold-formed steel lipped channel built-up I beam with intermediate web stiffener. Int. J. Adv. Struct. Eng. 2019, 11, 97-107. [CrossRef]

55. Manikandan, P.; Sukumar, S.; Kannan, K. Distortional buckling behaviour of intermediate cold-formed steel lipped channel section with various web stiffeners under compression. Int. J. Adv. Struct. Eng. 2018, 10, 189-198. [CrossRef]

56. Babu, S.S.; Selvan, S.S. Study on the flexural and compressive behavior of cold-formed steel sections with and without lips. Mater. Today Proc. 2021, 37, 265-272. [CrossRef]

57. Chen, B.; Roy, K.; Uzzaman, A.; Raftery, G.M.; Lim, J.B.P. Parametric study and simplified design equations for cold-formed steel channels with edge-stiffened holes under axial compression. J. Constr. Steel Res. 2020, 172, 106161. [CrossRef]

58. Chen, B.; Roy, K.; Uzzaman, A.; Raftery, G.; Lim, J.B.P. Axial strength of back-to-back cold-formed steel channels with edgestiffened holes, un-stiffened holes and plain webs. J. Constr. Steel Res. 2020, 174, 106313. [CrossRef]

59. Uzzaman, A.; Lim, J.B.P.; Nash, D.; Roy, K. Web crippling behaviour of cold-formed steel channel sections with edge-stiffened and unstiffened circular holes under interior-two-flange loading condition. Thin-Walled Struct. 2020, 154, 106813. [CrossRef]

60. Chen, B.; Roy, K.; Uzzaman, A.; Lim, J.B.P. Moment capacity of cold-formed channel beams with edge-stiffened web holes, un-stiffened web holes and plain webs. Thin-Walled Struct. 2020, 157, 107070. [CrossRef]

61. Chen, B.; Roy, K.; Fang, Z.; Uzzaman, A.; Chi, Y.; Lim, J.B.P. Web crippling capacity of fastened cold-formed steel channels with edge-stiffened web holes, un-stiffened web holes and plain webs under two-flange loading. Thin-Walled Struct. 2021, 163, 107666. [CrossRef]

62. Fang, Z.; Roy, K.; Chi, Y.; Chen, B.; Lim, J.B.P. Finite element analysis and proposed design rules for cold-formed stainless steel channels with web holes under end-one-flange loading. Structures 2021, 34, 2876-2899. [CrossRef]

63. Fang, Z.; Roy, K.; Uzzaman, A.; Lim, J.B.P. Numerical simulation and proposed design rules of cold-formed stainless steel channels with web holes under interior-one-flange loading. Eng. Struct. 2021, 113566. [CrossRef]

64. Fang, Z.; Roy, K.; Liang, H.; Poologanathan, K.; Ghosh, K.; Mohamed, A.M.; Lim, J.B.P. Numerical Simulation and Design Recommendations for Web Crippling Strength of Cold-Formed Steel Channels with Web Holes under Interior-One-Flange Loading at Elevated Temperatures. Buildings 2021, 11, 666. [CrossRef]

65. Chen, B.; Roy, K.; Fang, Z.; Uzzaman, A.; Pham, C.; Raftery, G.; Lim, J. Shear capacity of cold-formed steel channels with edge-stiffened web holes, un-stiffened web holes and plain webs. J. Struct. Eng. 2022, 148, 04021268. [CrossRef]

66. Selvaraj, S.; Madhavan, M. Structural design of cold-formed steel face-to-face connected built-up beams using direct strength method. J. Constr. Steel Res. 2019, 160, 613-628. [CrossRef]

67. Zhang, J.-H.; Young, B. Compression tests of cold-formed steel I-shaped open sections with edge and web stiffeners. Thin-Walled Struct. 2012, 52, 1-11. [CrossRef]

68. Craveiro, H.D.; Rodrigues, J.P.C.; Laím, L. Buckling resistance of axially loaded cold-formed steel columns. Thin-Walled Struct. 2016, 106, 358-375. [CrossRef]

69. Lu, Y.; Zhou, T.; Li, W.; Wu, H. Experimental investigation and a novel direct strength method for cold-formed built-up I-section columns. Thin-Walled Struct. 2017, 112, 125-139. [CrossRef]

70. Roy, K.; Mohammadjani, C.; Lim, J.B.P. Experimental and numerical investigation into the behaviour of face-to-face built-up cold-formed steel channel sections under compression. Thin-Walled Struct. 2019, 134, 291-309. [CrossRef]

71. Meza, F.J.; Becque, J.; Hajirasouliha, I. Experimental study of cold-formed steel built-up columns. Thin-Walled Struct. 2020, 149, 106291. [CrossRef] 
72. Meza, F.J.; Becque, J.; Hajirasouliha, I. Experimental study of the cross-sectional capacity of cold-formed steel built-up columns. Thin-Walled Struct. 2020, 155, 106958. [CrossRef]

73. Roy, K.; Ting, T.C.H.; Lau, H.H.; Lim, J.B.P. Effect of thickness on the behaviour of axially loaded back-to-back cold-formed steel built-up channel sections-Experimental and numerical investigation. Structures 2018, 16, 327-346. [CrossRef]

74. Roy, K.; Lau, H.H.; Ting, T.C.H.; Chen, B.; Lim, J.B.P. Flexural capacity of gapped built-up cold-formed steel channel sections including web stiffeners. J. Constr. Steel Res. 2020, 172, 106154. [CrossRef]

75. Sani, M.S.H.M.; Muftah, F.; Osman, A.R. A review and development of cold-formed steel channel columns with oriented strand board sections. Mater. Today Proc. 2019, 17, 1078-1085. [CrossRef]

76. Roy, K.; Ting, T.C.H.; Lau, H.H.; Lim, J.B.P. Experimental and numerical investigations on the axial capacity of cold-formed steel built-up box sections. J. Constr. Steel Res. 2019, 160, 411-427. [CrossRef]

77. Roy, K.; Ting, T.C.H.; Lau, H.H.; Lim, J.B.P. Nonlinear behaviour of back-to-back gapped built-up cold-formed steel channel sections under compression. J. Constr. Steel Res. 2018, 147, 257-276. [CrossRef]

78. Roy, K.; Ting, T.; Lau, H.H.; Lim, J. Nonlinear behavior of axially loaded back-to-back built-up cold-formed steel un-lipped channel sections. Steel Comp. Struct. 2018, 28, 233-250.

79. Roy, K.; Lim, J.B.P. Numerical investigation into the buckling behaviour of face-to-face built-up cold-formed stainless steel channel sections under axial compression. Structures 2019, 20, 42-73. [CrossRef]

80. Roy, K.; Ho Lau, H.; Ting, T.C.H.; Chen, B.; Lim, J.B.P. Flexural behaviour of back-to-back built-up cold-formed steel channel beams: Experiments and finite element modelling. Structures 2021, 29, 235-253. [CrossRef]

81. Fang, Z.; Roy, K.; Chen, B.; Xie, Z.; Lim, J.B.P. Local and distortional buckling behaviour of aluminium alloy back-to-back channels with web holes under axial compression. J. Build. Eng. 2021, 47, 103837. [CrossRef]

82. Chen, B.; Roy, K.; Fang, Z.; Uzzaman, A.; Raftery, G.; Lim, J.B.P. Moment capacity of back-to-back cold-formed steel channels with edge-stiffened holes, un-stiffened holes, and plain webs. Eng. Struct. 2021, 235, 112042. [CrossRef]

83. Roy, K.; Chen, B.; Fang, Z.; Uzzaman, A.; Chen, X.; Lim, J.B.P. Local and distortional buckling behaviour of back-to-back built-up aluminium alloy channel section columns. Thin-Walled Struct. 2021, 163, 107713. [CrossRef]

84. Nie, S.; Zhou, T.; Eatherton, M.R.; Li, J.; Zhang, Y. Compressive behavior of built-up double-box columns consisting of four cold-formed steel channels. Eng. Struct. 2020, 222, 111133. [CrossRef]

85. Chi, Y.; Roy, K.; Chen, B.; Fang, Z.; Uzzaman, A.; Ananthi, G.B.; Lim, J. Effect of web hole spacing on axial capacity of back-to-back cold-formed steel channels with edge-stiffened holes. Steel Comp. Struct. 2021, 40, 287-305.

86. Roy, K.; Chen, B.; Fang, Z.; Uzzaman, A.; Lim, J. Axial capacity of back-to-back built-up aluminium alloy channel section columns. J. Struct. Eng. 2022, 148, 04021265. [CrossRef]

87. Roy, K.; Lau, H.H.; Lim, J. Finite element modelling of back-to-back built-up cold-formed stainless-steel lipped channels under axial compression. Steel Comp. Struct. 2019, 33, 37-66.

88. Ananthi, G.B.G.; Roy, K.; Chen, B.; Lim James, B.P. Testing, simulation and design of back-to-back built-up cold-formed steel unequal angle sections under axial compression. Steel Comp. Struct. 2019, 33, 595-614.

89. Ananthi, G.B.; Roy, K.; Lim, J. Experimental and numerical investigations on axial strength of back-to-back built-up cold-formed steel angle columns. Steel Comp. Struct. 2019, 31, 605-615.

90. Roy, K.; Lau, H.H.; Lim, J. Numerical investigations on the axial capacity of back-to-back gapped built-up cold-formed stainless steel channels. Adv. Struct. Eng. 2019, 22, 2289-2310. [CrossRef]

91. Ye, J.; Mojtabaei, S.M.; Hajirasouliha, I. Local-flexural interactive buckling of standard and optimised cold-formed steel columns. J. Constr. Steel Res. 2018, 144, 106-118. [CrossRef]

92. Ye, J.; Hajirasouliha, I.; Becque, J. Experimental investigation of local-flexural interactive buckling of cold-formed steel channel columns. Thin-Walled Struct. 2018, 125, 245-258. [CrossRef]

93. Bedair, O. Design formulas for channels subject to combined compression, shear and major axis bending. Asian J. Civil Eng. 2021, 22, 101-109. [CrossRef]

94. Ammash, H.K. Shape optimization of innovation cold-formed steel columns under uniaxial compressive loading. Jordan J. Civil Eng. 2017, 11, 3 .

95. Hancock, G.J.; Pham, C.H. New Section Shapes Using High-Strength Steels in Cold-Formed Steel Structures in Australia, in Recent Trends in Cold-Formed Steel Construction; Yu, C., Ed.; Woodhead Publishing: Sawston, UK, 2016; pp. 221-239.

96. Oey, O.; Papangelis, J. Behaviour of cold-formed steel channels bent about the minor axis. Thin-Walled Struct. 2021, 164, 107781. [CrossRef]

97. Peiris, M.; Mahendran, M. Behaviour of cold-formed steel lipped channel sections subject to eccentric axial compression. J. Constr. Steel Res. 2021, 184, 106808. [CrossRef]

98. Phan, D.T.; Mojtabaei, S.M.; Hajirasouliha, I.; Ye, J.; Lim, J.B.P. Coupled element and structural level optimisation framework for cold-formed steel frames. J. Constr. Steel Res. 2020, 168, 105867. [CrossRef]

99. Janarthanan, B.; Mahendran, M.; Gunalan, S. Numerical modelling of web crippling failures in cold-formed steel unlipped channel sections. J. Constr. Steel Res. 2019, 158, 486-501. [CrossRef]

100. Chen, Y.; Chen, X.; Wang, C. Experimental and finite element analysis research on cold-formed steel lipped channel beams under web crippling. Thin-Walled Struct. 2015, 87, 41-52. [CrossRef] 
101. Uzzaman, A.; Lim, J.B.P.; Nash, D.; Roy, K. Cold-formed steel channel sections under end-two-flange loading condition: Design for edge-stiffened holes, unstiffened holes and plain webs. Thin-Walled Struct. 2020, 147, 106532. [CrossRef]

102. AISI. AISI S100-16; North American Specification for the Design of Cold-Formed Steel Structural Members. American Iron and Steel Institute: Washington, DC, USA, 2016.

103. AS/NZS. AS/NZS 4600:2018; Cold-Formed Steel Structures. Standards Australia/Standards New Zealand. Australian/New Zealand Standard: Sydney, Australia, 2018.

104. EuroCode-3; Design of Steel Structures, Part 1.3: General Rules for Cold Formed Thin Gauge Members and Sheeting. British Standard Institution: London, UK, 1996.

105. Torabian, S.; Zheng, B.; Schafer, B.W. Experimental response of cold-formed steel lipped channel beam-columns. Thin-Walled Struct. 2015, 89, 152-168. [CrossRef]

106. Camotim, D.; Dinis, P.B.; Martins, A.D. Direct Strength Method-A General Approach for the Design of Cold-Formed Steel Structures. In Recent Trends in Cold-Formed Steel Construction; Yu, C., Ed.; Woodhead Publishing: Sawston, UK, 2016 ; pp. 69-105.

107. Fang, Z.Y.; Roy, K.; Chen, B.S.; Sham, C.-W.; Hajirasouliha, I.; Lim, J.B.P. Deep learning-based procedure for structural design of cold-formed steel channel sections with edge-stiffened and un-stiffened holes under axial compression. Thin-Walled Struct. 2021, 166, 108076. [CrossRef]

108. Fang, Z.Y.; Roy, K.; Mares, J.; Sham, C.-W.; Chen, B.S.; Lim, J.B.P. Deep learning-based axial capacity prediction for cold-formed steel channel sections using Deep Belief Network. Structures 2021, 33, 2792-2802. [CrossRef]

109. Fang, Z.Y.; Roy, K.; Padiyara, S.; Uzzaman, A.; Chen, B.S.; Lim, J.B.P. Deep learning application on web crippling design of cold-formed stainless steel channel sections with web holes under interior-two-flange loading condition. Eng. Struct. 2021, under review.

110. Fang, Z.Y.; Roy, K.; Ma, Q.; Uzzaman, A.; Lim, J.B.P. Application of deep learning method in web crippling strength prediction of cold-formed stainless steel channel sections under end-two-flange loading. Structures 2021, 33, 2903-2942. [CrossRef]

111. Gatheeshgar, P.; Poologanathan, K.; Gunalan, S.; Tsavdaridis, K.D.; Nagaratnam, B.; Iacovidou, E. Optimised cold-formed steel beams in modular building applications. J. Build. Eng. 2020, 32, 101607. [CrossRef]

112. Leng, J.; Li, Z.; Guest, J.K.; Schafer, B.W. Shape optimization of cold-formed steel columns with fabrication and geometric end-use constraints. Thin-Walled Struct. 2014, 85, 271-290. [CrossRef]

113. Leng, J.; Guest, J.K.; Schafer, B.W. Shape optimization of cold-formed steel columns. Thin-Walled Struct. 2011, 49 , 1492-1503. [CrossRef]

114. Sharafi, P.; Teh, L.H.; Hadi, M.N.S. Shape optimization of thin-walled steel sections using graph theory and ACO algorithm. J. Constr. Steel Res. 2014, 101, 331-341. [CrossRef]

115. Madeira, J.F.A.; Dias, J.; Silvestre, N. Multiobjective optimization of cold-formed steel columns. Thin-Walled Struct. 2015, 96, 29-38. [CrossRef]

116. Tran, T.; Li, L.-Y. Global optimization of cold-formed steel channel sections. Thin-Walled Struct. 2006, 44, 399-406. [CrossRef]

117. Lee, J.; Kim, S.-M.; Seon Park, H. Optimum design of cold-formed steel columns by using micro genetic algorithms. Thin-Walled Struct. 2006, 44, 952-960. [CrossRef]

118. Lee, J.; Kim, S.-M.; Park, H.-S.; Woo, B.-H. Optimum design of cold-formed steel channel beams using micro Genetic Algorithm. Eng. Struct. 2005, 27, 17-24. [CrossRef]

119. Ma, W.; Becque, J.; Hajirasouliha, I.; Ye, J. Cross-sectional optimization of cold-formed steel channels to Eurocode 3. Eng. Struct. 2015, 101, 641-651. [CrossRef]

120. Wang, B.; Gilbert, B.P.; Guan, H.; Teh, L.H. Shape optimisation of manufacturable and usable cold-formed steel singly-symmetric and open columns. Thin-Walled Struct. 2016, 109, 271-284. [CrossRef]

121. Wang, B.; Bosco, G.L.; Gilbert, B.P.; Guan, H.; Teh, L.H. Unconstrained shape optimisation of singly-symmetric and open cold-formed steel beams and beam-columns. Thin-Walled Struct. 2016, 104, 54-61. [CrossRef]

122. Moharrami, M.; Louhghalam, A.; Tootkaboni, M. Optimal folding of cold formed steel cross sections under compression. Thin-Walled Struct. 2014, 76, 145-156. [CrossRef]

123. Guimarães, V.M.; Gilbert, B.P.; Talebian, N.; Wang, B. Shape optimisation of singly-symmetric cold-formed steel purlins. Thin-Walled Struct. 2021, 161, 107402. [CrossRef]

124. Dias, Y.; Mahendran, M. Shape optimisation of cold-formed steel framed wall studs with sheathing restraints. Thin-Walled Struct. 2021, 158, 107135. [CrossRef]

125. Ye, J.; Becque, J.; Hajirasouliha, I.; Mojtabaei, S.M.; Lim, J.B.P. Development of optimum cold-formed steel sections for maximum energy dissipation in uniaxial bending. Eng. Struct. 2018, 161, 55-67. [CrossRef]

126. Ye, J.; Hajirasouliha, I.; Becque, J.; Eslami, A. Optimum design of cold-formed steel beams using Particle Swarm Optimisation method. J. Constr. Steel Res. 2016, 122, 80-93. [CrossRef]

127. Perampalam, G.; Poologanathan, K.; Gunalan, S.; Ye, J.; Nagaratnam, B. Optimum design of cold-formed steel beams: Particle swarm optimisation and numerical analysis. ce/papers 2019, 3, 205-210. [CrossRef]

128. Gatheeshgar, P.; Poologanathan, K.; Gunalan, S.; Nagaratnam, B.; Tsavdaridis, K.D.; Ye, J. Structural behaviour of optimized cold-formed steel beams. Steel Constr. 2020, 13, 294-304. [CrossRef]

129. Li, Z.; Leng, J.; Guest, J.K.; Schafer, B.W. Two-level optimization for a new family of cold-formed steel lipped channel sections against local and distortional buckling. Thin-Walled Struct. 2016, 108, 64-74. [CrossRef] 
130. Gatheeshgar, P.; Poologanathan, K.; Gunalan, S.; Shyha, I.; Tsavdaridis, K.D.; Corradi, M. Optimal design of cold-formed steel lipped channel beams: Combined bending, shear, and web crippling. Structures 2020, 28, 825-836. [CrossRef]

131. Mojtabaei, S.M.; Ye, J.; Hajirasouliha, I. Development of optimum cold-formed steel beams for serviceability and ultimate limit states using Big Bang-Big Crunch optimisation. Eng. Struct. 2019, 195, 172-181. [CrossRef]

132. Gilbert, B.P.; Savoyat, T.J.M.; Teh, L.H. Self-shape optimisation application: Optimisation of cold-formed steel columns. Thin-Walled Struct. 2012, 60, 173-184. [CrossRef]

133. Shimoda, M.; Liu, Y.; Ishikawa, K. Optimum shape design of thin-walled cross sections using a parameter-free optimization method. Thin-Walled Struct. 2020, 148, 106603. [CrossRef]

134. Tashakori, A.; Adeli, H. Optimum design of cold-formed steel space structures using neural dynamics model. J. Constr. Steel Res. 2002, 58, 1545-1566. [CrossRef]

135. Adeli, H.; Karim, A. Neural network model for optimization of cold-formed steel beams. J. Struct. Eng. 1997, $123,1535-1543$. [CrossRef]

136. Kripka, M.; Chamberlain Pravia Zacarias, M. Cold-formed steel channel columns optimization with simulated annealing method. Struct. Eng. Mech. 2013, 48, 383-394. [CrossRef]

137. Liu, H.; Igusa, T.; Schafer, B.W. Knowledge-based global optimization of cold-formed steel columns. Thin-Walled Struct. 2004, 42, 785-801. [CrossRef]

138. Tian, Y.S.; Lu, T.J. Minimum weight of cold-formed steel sections under compression. Thin-Walled Struct. 2004, 42, 515-532. [CrossRef]

139. Ostwald, M.; Rodak, M. Multicriteria optimization of cold-formed thin-walled beams with generalized open shape under different loads. Thin-Walled Struct. 2013, 65, 26-33. [CrossRef]

140. Al-Mosawi, S.; Saka, M.P. Optimum shape design of cold-formed thin-walled steel sections. Adv. Eng. Soft. 2000, 31, 851-862. [CrossRef]

141. AISI. InstituteAISI S100-07; North American Specification for the Design of Cold-formed Steel Structural Members. American Iron and Steel: Washington, DC, USA, 2007.

142. British Standard Institution. BS5950: Structural Use of Steel in Building: Part 5: Code of Practice for Design of Cold Formed Sections; British Standard Institution: London, UK, 1998.

143. Moradibistouni, M.; Vale, B.; Isaacs, N. A life cycle study of insulation in a case study building with a focus on the effect of the national energy profile. J. Build. Eng. 2021, 43, 103178. [CrossRef]

144. Ministry of Business, Innovation and Employment. Transforming Operational Efficiency. Available online: https://www.mbie. govt.nz/dmsdocument/11793-transforming-operational-efficiency (accessed on 11 November 2021).

145. Santos, P.; Gervásio, H.; da Silva, L.S.; Lopes, A.G. Influence of climate change on the energy efficiency of lightweight steel residential buildings. Civ. Eng. Environ. Syst. 2011, 28, 325-352. [CrossRef]

146. Santos, P.; Lemes, G.; Mateus, D. Thermal Transmittance of Internal Partition and External Facade LSF Walls: A Parametric Study. Energies 2019, 12, 2671. [CrossRef]

147. Cianfrone, C.; Roppel, P.; Hardock, D. Holistic approach to achieving low-energy, high-rise residential buildings. J. Build. Phys. 2016, 39, 522-541. [CrossRef]

148. Lucchi, E.; Becherini, F.; Di Tuccio, M.C.; Troi, A.; Frick, J.; Roberti, F.; Hermann, C.; Fairnington, I.; Mezzasalma, G.; Pockelé, L.; et al. Thermal performance evaluation and comfort assessment of advanced aerogel as blown-in insulation for historic buildings. Build. Environ. 2017, 122, 258-268. [CrossRef]

149. Kumar, D.; Zou, P.X.W.; Memon, R.A.; Alam, M.D.M.; Sanjayan, J.G.; Kumar, S. Life-cycle cost analysis of building wall and insulation materials. J. Build. Phys. 2019, 43, 428-455. [CrossRef]

150. Kapoor, D.R.; Peterman, K.D. Quantification and prediction of the thermal performance of cold-formed steel wall assemblies. Structures 2021, 30, 305-315. [CrossRef]

151. Tejedor, B.; Barreira, E.; Almeida, R.M.S.F.; Casals, M. Thermographic 2D $U$-value map for quantifying thermal bridges in building façades. Energy Build. 2020, 224, 110176. [CrossRef]

152. Jiang, X.; Lin, A.; Ma, H.; Li, X.; Li, Y. Minimizing the thermal bridge through the columns in a refrigeration room. Appl. Therm. Eng. 2020, 165, 114565. [CrossRef]

153. Gomes, A.P.; de Souza, H.A.; Tribess, A. Impact of thermal bridging on the performance of buildings using Light Steel Framing in Brazil. Appl. Therm. Eng. 2013, 52, 84-89. [CrossRef]

154. Pelss, M.; Blumberga, A.; Kamenders, A. Thermal bridge impact on the heating demand in a low-energy house. Rigas Teh. Univ. Zinat. Raksti 2010, 4, 76. [CrossRef]

155. Collins, N. Light Steel Framing: H1 achieving international best practice. In NASH Research Scope; NASH, National Association of Steel Framed Housing: Hartwell, Australia, 2021.

156. Santos, P.; Lemes, G.; Mateus, D. Analytical methods to estimate the thermal transmittance of lsf walls: Calculation procedures review and accuracy comparison. Energies 2020, 13, 840. [CrossRef]

157. Santos, P.; Gonçalves, M.; Martins, C.; Soares, N.; Costa, J.J. Thermal transmittance of lightweight steel framed walls: Experimental versus numerical and analytical approaches. J. Build. Eng. 2019, 25, 100776. [CrossRef]

158. Gorgolewski, M. Developing a simplified method of calculating $U$-values in light steel framing. Build. Environ. 2007, 42, 230-236. [CrossRef] 
159. ISO 6946; Building Components and Building Elements Thermal Resistance and Thermal Transmittance-Calculation Methods. International Organization for Standardization: Geneva, Switzerland, 2017.

160. ASHRAE. Handbook of Fundamentals (SI Edition); ASHRAE—American Society of Heating, Refrigerating and Air-Conditioning Engineers: Atlanta, GA, USA, 2017.

161. Soares, N.; Martins, C.; Gonçalves, M.; Santos, P.; da Silva, L.S.; Costa, J.J. Laboratory and in-situ non-destructive methods to evaluate the thermal transmittance and behavior of walls, windows, and construction elements with innovative materials: A review. Energy Build. 2019, 182, 88-110. [CrossRef]

162. Santos, P.; Simões da Silva, L.; Gervásio, H.; Gameiro Lopes, A. Parametric analysis of the thermal performance of light steel residential buildings in Csb climatic regions. J. Build. Phys. 2011, 35, 7-53. [CrossRef]

163. Lupan, L.M.; Manea, D.L.; Moga, L.M. Improving thermal performance of the wall panels using slotted steel stud framing. Procedia Technol. 2016, 22, 351-357. [CrossRef]

164. Beggas, D.; Zeghiche, J. The use of slag stone concrete to improve the thermal performance of light steel buildings. Sustain. Cities Soc. 2013, 6, 22-26. [CrossRef]

165. Ribeiro, T. Thermal performance of double-pane lightweight steel framed walls with and without a reflective foil. Buildings 2021, $11,301$.

166. Kempton, L.; Kokogiannakis, G.; Green, A.; Cooper, P. Evaluation of thermal bridging mitigation techniques and impact of calculation methods for lightweight steel frame external wall systems. J. Build. Eng. 2021, 43, 102893. [CrossRef]

167. Atsonios, I.A.; Mandilaras, I.D.; Kontogeorgos, D.A.; Founti, M.A. Two new methods for the in-situ measurement of the overall thermal transmittance of cold frame lightweight steel-framed walls. Energy Build. 2018, 170, 183-194. [CrossRef]

168. Steau, E.; Mahendran, M. Elevated temperature thermal properties of fire protective boards and insulation materials for light steel frame systems. J. Build. Eng. 2021, 43, 102571. [CrossRef]

169. de Angelis, E.; Serra, E. Light steel-frame walls: Thermal insulation performances and thermal bridges. Energy Procedia 2014, 45, 362-371. [CrossRef]

170. Lohmann, V.; Santos, P. Trombe wall thermal behavior and energy efficiency of a light steel frame compartment: Experimental and numerical assessments. Energies 2020, 13, 2744. [CrossRef]

171. Buzatu, R.; Muntean, D.; Ciutina, A.; Ungureanu, V. Thermal performance and energy efficiency of lightweight steel buildings: A case-study. IOP Conf. Ser. Mater. Sci. Eng. 2020, 960, 032099. [CrossRef]

172. Li, Y.; Yao, J.; Li, R.; Zhang, Z.; Zhang, J. Thermal and energy performance of a steel-bamboo composite wall structure. Energy Build. 2017, 156, 225-237. [CrossRef]

173. Borelli, D.; Cavalletti, P.; Marchitto, A.; Schenone, C. A comprehensive study devoted to determine linear thermal bridges transmittance in existing buildings. Energy Build. 2020, 224, 110136. [CrossRef]

174. Samiee, P.; Esmaeili Niari, S.; Ghandi, E. Thermal and structural behavior of cold-formed steel frame wall under fire condition. Eng. Struct. 2021; 113563, in Press.

175. Orzechowski, T.; Orzechowski, M. Optimal thickness of various insulation materials for different temperature conditions and heat sources in terms of economic aspect. J. Build. Phys. 2017, 41, 377-393. [CrossRef]

176. Tažiková, A.; Struková, Z. An Assessment and Comparative Study of Modern Thermal Insulation Systems. TEM J. 2018, 7, 769-774.

177. Oliveira, R.; Almeida, R.; Vicente, R.; Roque, E.; Figueiredo, A. Lightweight and prefabricated construction as a path to energy efficient buildings: Thermal design and execution challenges. Int. J. Environ. Sustain. Dev. 2020, 19, 1-32. [CrossRef]

178. Petcu, C.; Petran, H.-A.; Vasile, V.; Toderasc, M.-C. Materials from Renewable Sources as Thermal Insulation for Nearly Zero Energy Buildings (nZEB). In Nearly Zero Energy Communities; Springer International Publishing: Cham, Switzerland, 2018.

179. Rodrigues, L.; White, J.; Gillott, M.; Braham, E.; Ishaque, A. Theoretical and experimental thermal performance assessment of an innovative external wall insulation system for social housing retrofit. Energy Build. 2018, 162, 77-90. [CrossRef]

180. Khan, N.A.; Bhattacharjee, B. Thermal and noise insulation performance interaction of building envelope during building simulation optimization in tropical climates. Build. Environ. 2021, 200, 107948. [CrossRef] 